\title{
عمليات البورصة وأوامر العملاء بين القانون التجاري والفقه الإسلامي
}

\author{
إعداد الدكتور \\ محمد فراج عمر فراج \\ أستاذ مساعد بقسم القانون \\ كلية الثريعة والقانون جامعة الجوف
}



عمليات البورصة وأوامر العملاء بين القانون التجاري والفقه الإسلامي

محمد فراج عمر فراج

قسم القانون، كلية الثريعة والقانون، جامعة الجوف، المملكة العربية السعودية.

Mffarag@ju.edu.sa : البريد الألكتروني

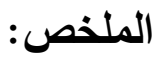

تهدف هذه الاراسة إلى:

- دراسة عمليات بورصة الأوراق المالية بأنواعها المتعددة ، سواء العمليات الحاضرة. أو العمليات الآجلة. وهي منتوعة من بورصة إلي أخري ، ومن بلد إلي أخري ، وتلك العمليات باتة تتم وفق عقود رضائية . وقد توصلت الدراسة إلى عدة نتائج منها: - أن المشرع المصري قد أجاز الشراء استثناء علي التزام المشتري بسداد كامل الثمن أجاز اقتراض الأوراق المالية بغرض البيع (البيع علي المكثوف ) استثناءً علي التزام البائع بتسليم أوراق مالية مملوكة له بالكامل ، - أن المشرع المصري قد نص في اللائحة التتفيذية لقانون راس المال رقم لسنة ب991 م علي أنه يحب علي الثركة السمسرة تسجيل أوامر العملاء فور ورودها إليها، وبثمن التسجيل مضدون الأمر واسم مصدره وصفته وساعته وكيفية وروده الى الثركة، والثنن الذى يرغب العيل التعامل به ويجب ان يكون وقت تتفيذ أمر البورصة محدداً سواء كان يوماً أو أسبوعاً أو شهراً . - ومن ناحية الثريعة الإسلامية فقد وجدنا خلافاً فقهياً غنياً بالآراء والأدلة بين العلماء المجيزين لتلك العمليات والمانعين لها وخلصت إلى أن العمليات الآجلة الباتة القطعية جائزة شرعاً وذلك طالما أن الأوراق المالية محل تلك العمليات يجوز

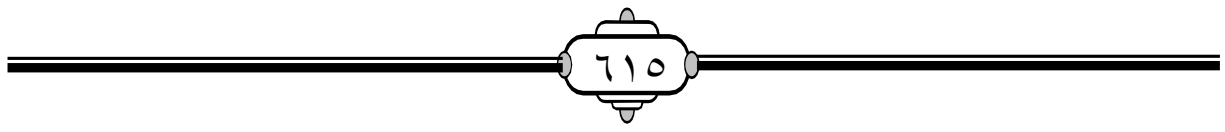


التعامل عليها ويملك المشترى المبيع ويملك البائع الثمن ويكون ملك المشترى للمبيع بمجرد عقد البيع الصحيح ولا يتوقف على التقابض • وإن كان للتقابض أثره لكن عند الضمان • ولا تقاس على عقد السلم ولا البيع إلى أجل ولكنها عقد بيع آجل فيه تسليم كل من البدلين.

وقد أوصى الباحث بعدة توصيات منها:

1-ضرورة توجيه القائمين على دراسة وتدريس العلوم الثرعية ومنها ما يخصنا وهو فقه المعاملات إلى دراسة الأصول القانونية والاقتصادية للمعاملات المعاصرة ، حتى يتسنى لهم تكييف تلاك المعاملات من الناحية الثرعية السليمة وإصدار الأحكام الثرعية لتلك المعاملات في ضوء مقررات وقواعد الشريعة الإسلامية الغراء. ץ- ضرورة تبصير وتوعية جمهور المتعاملين في البورصة بأحكام الثريعة الإسلامية لتلك العمليات التي يقومون بها ومعرفة ماهي الأوراق المالية التي يجوز لهم أن يتعاملوا بها وما هي تلك التي يحرم عليهح التعامل فيها. r- ضرورة قيام دراسات قانونية اقتصادية شرعية تتبثق من لجان متخصصة تعمل جاهدة على استحداث أدوات مالية إسلامية بديلة عن تلك الأوراق المالية التي حكم الثرع الإسلامي بعدم جواز التعامل بها ـ وهذا ما قامت به فعلاً بعض الدول الإسلامية ، ومن تلك الأوراق المالية الإسلامية سندات المقارضة الإسلامية وفقاً لقواعد الثريعة الإسلامية ووثائق

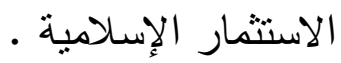
الكلمات المفتاحية : بورصة - أوراق مالية - العمليات الحاضرة - العمليات العرة الآجلة - أوامر العملاء - شركة السمسرة .

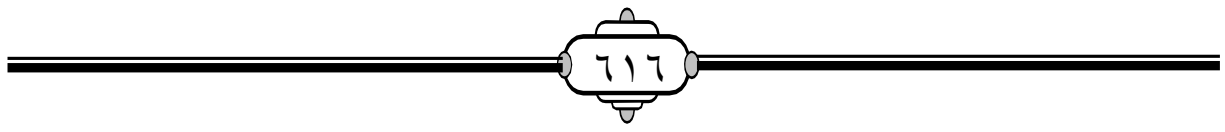


عمليات البورصة وأوامر العملاء بين القانون التجاري والفقه الإسلامي

\section{Stock exchange operations and customer orders}

Between commercial law jurisprudence

\section{Mohammed Farrag Omar Farrag}

Jouf -Law Department, College of Sharia and Law, Al

University, Kingdom of Saudi Arabia

Email: Mffarag@ju.edu.sa

\section{Abstract}

\section{:This study aims to}

- Study stock exchange operations of all kinds, both the present operations. Or forward operations. They vary from one exchange to another, and from one country to another, and these operations are now carried out according to .consensual contracts

:The study reached several results, including

- lator has authorized the purchase as an The Egyptian legis exception to the buyer's obligation to pay the full price. It permits the borrowing of securities for the purpose of selling short selling), as an exception to the seller's obligation to ) .wned by himhand over securities fully 0

- The Egyptian legislator has stipulated in the executive $A D$ that the 199rof 9 oregulations of the Capital Law No.

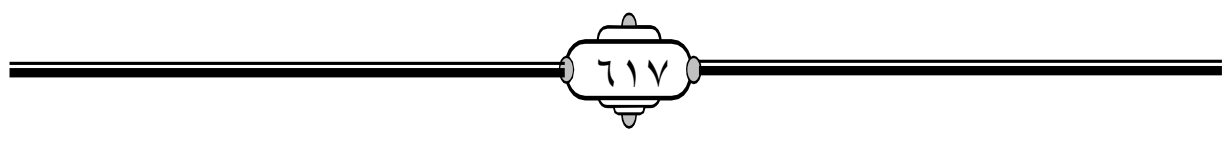


brokerage company must record clients' orders as soon as they are received, and at the registration price the content of er, the name of its source, its description, its time, the the ord method of its arrival to the company, and the price that the client wishes to deal with and must The time for executing the stock exchange order is specified, whether it is a day, a week .or a month

- In terms of Islamic law, we have found a jurisprudential disagreement rich in opinions and evidence between scholars who permit these operations and those who refuse them, and concluded that definitive future operations are permissible a as long as the securities that are the according to Shari subject of those operations may be dealt with and the buyer owns the sale and the seller owns the price, and the buyer owns the sale by merely contracting The right sale does not adiction has an effect, depend on the exchange. If the contr but at the guarantee. It is not measured as a contract of peace or sale to a term, but it is a deferred sale contract in .which the two alternatives are delivered

The researcher recommended several recommendations, :including

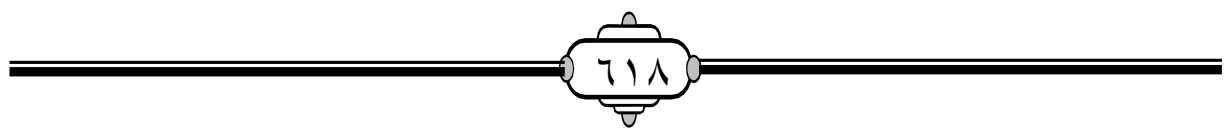


4- necessity of directing those in charge of studying The and teaching Sharia sciences, including what concerns us, which is the jurisprudence of transactions, to study the legal and economic principles of contemporary ransactions transactions, so that they can adapt these $\mathrm{t}$ from a sound Sharia perspective and issue Sharia rulings for those transactions in light of the decisions .and rules of the glorious Islamic Sharia 5- The necessity of enlightening and educating the public the provisions of of dealers in the stock exchange about Islamic Sharia law for those operations that they carry out and knowing what securities they may deal with and .what are those that are forbidden for them to deal in 6- The necessity of establishing legitimate economic and nating from specialized committees legal studies ema working hard to develop Islamic financial instruments alternative to those securities that the Islamic Sharia ruled that it is not permissible to deal with them. This is what some Islamic countries have actually done, and among those Islamic securities are Islamic Muqaradah

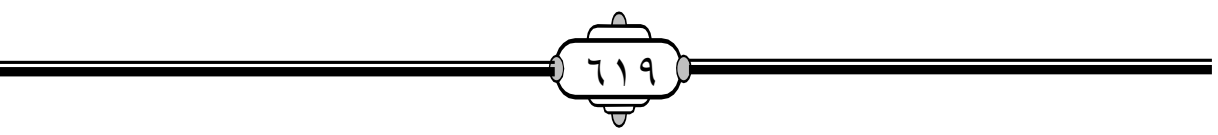


عمليات البورصة واوامر العملاء بين القانون التجاري والفقه الإسلامي

bonds in accordance with the rules of Islamic Sharia .and Islamic investment documents

key words:Market-Customer Securities Present processes -

-Forward operations Brokerage firm - orders

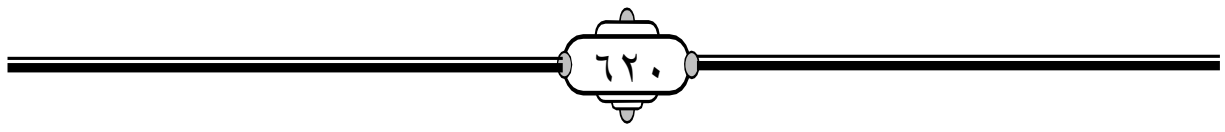




\section{ثمقدمبر}

بداية نستطيع أن نقول أن عمليات بورصة الأوراق المالية ليست نوعاً واحداً بل هي أنواع متعددة ، منها عمليات حاضرة ، يتم بمقتضاها تشليم الثثن إلي البائع مقابل أن يقوم هو بتسليم الأوراق المالية للمشتري فور إتمام تلك العمليات دون إبطاء أو تأخير • ومنها أيضاً عمليات آجلة. وهي متتوعة من بورصة إلي أخري ، ومن بلد إلي أخري ، فإذا تبايع الطرفان علي أن يتم تأجيل التسليم للأوراق المالية المبيعة ،وتأجيل دفع الثمن إلي يوم معين يتفقان عليه ، فهذا البيع يعد من العمليات الآجلة، وقد كانت ثلاك العمليات باتة تتم وفق عقود رضائية ، إلا أنه وجد أن بعض التجار كان يتراجع عن التنفيذ إذا رأي أنه في هي غير مصلحته الحالية ، فظهرت العليات الآجلة الثرطية ، وأياً كانت طبيعة عمليات البورصة ، فإن نقطة البداية هي صدور أمر من العميل إلي شركة السمسرة يطلب فيه منها أن تقوم بتتفيذ عملية بيع أو شراء لأوراق مالية لحسابه، فتقوم شركة السمسرة بتفيذ

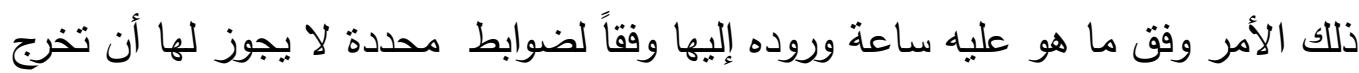
عنها وإلا كانت مسئولة عن ذلك وسوف أقدم هذا البحث في ثناثة مطالب علي النحو التالي :

المطلب الأول : عمليات البورصة في القانون . المطلب الثاني : أوامر العملاء لثركة السمسرة . المطلب الثالث : عمليات البورصة وأوامر العملاء في الفقه الإسلامي . 


\section{المطلب الأول \\ عمليات البورصة في القانون}

تقسم العمليات التي تكون الأوراق المالية محلاً لها إلي عمليات بورصة حاضرة ،وعمليات بورصة آجلة(') . وهي أهم أنواع التعاملات التي يتم تتفيذها في سوق الأوراق المالية علي يد شركات السمسرة العاملة في مجال تداول الأوراق المالية. ولذلك سوف أتناول نلاك العمليات الحاضرة والآجلة بشيء من التعربف وكي يتننى لنا معرفة نطاق تدخل شركات السمسرة ،هل يتضمن نوعي" العمليات في قانون سوق راس المال المصري ـ أم أنه قاصر علي العمليات الحاضرة فقط دون الآجلة التي لم يصدر بشأنها قرار بنظم أحكامها كسابقتها .

فعمليات البورصة إما أن تكون عمليات حاضرة (عاجلة ) أو تكون عمليات آجلة ، وقانون سوق رأس المال المصري لم يذكر في طياته نصاً يجيز التعامل الآجل في البورصة ، وإنما جاء النص عليها و علي جواز التعامل بها في القانون

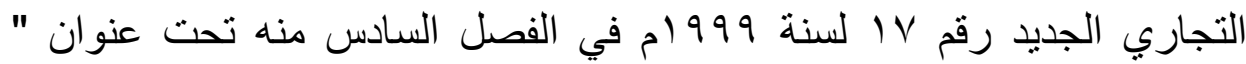

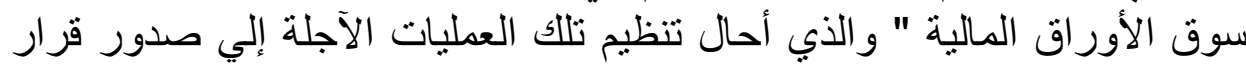
من الوزير المختص يقوم بتتظيمها (r) .

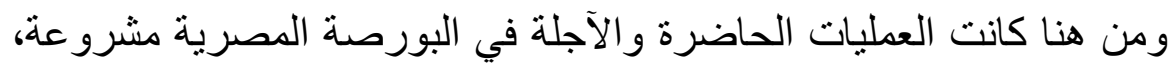
وسوف أتناول تعريف كلّ من نوعي هذه العمليات في مطلبين متتالين علي النحو التالي:

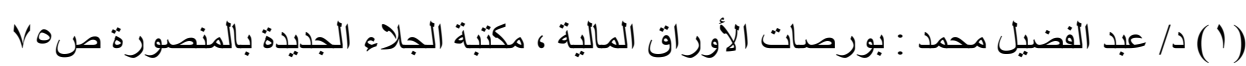
بند VT)

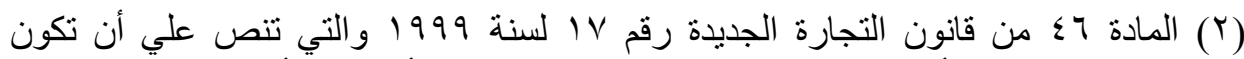

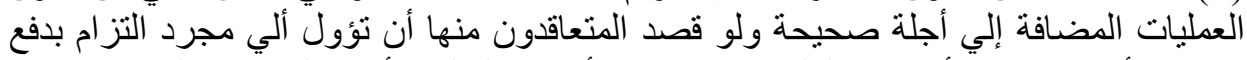

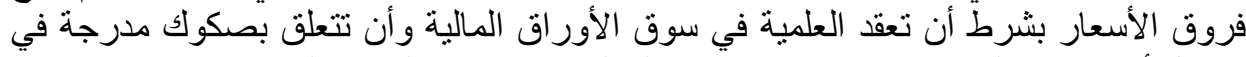

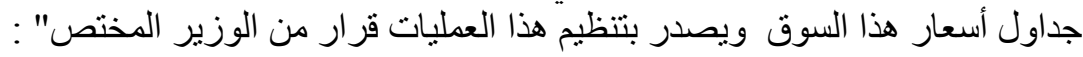

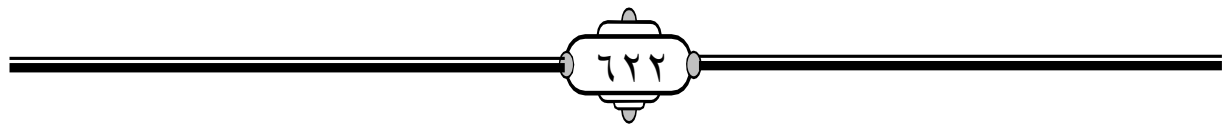


الفرع الأول: العمليات الحاضرة في البورصة.

الفرع الثاني : العمليات الآجلة في البورصة .

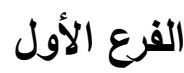

\section{العمليات الحاضرة في البورصة}

عمليات البورصة الحاضرة (') " au comptant" هي تللك العمليات التي يتم

تتفيذها على الفور عن طريق التسليم الفعلي للأوراق المالية والوفاء بالثمن (ّ). ويقصد بالأوراق المالية طويلة الأجل ( الأسهم والسندات ) وهي التي يتم إصدارها عن طريق منشآت الأعمال ، وكذللك الأوراق المالية التي تحتكر الحكومة إصدارها وتتاول في سوق الأوراق المالية، حيث يقوم المشتري بدفع قيمة الأوراق المالية التي اشتراها أو جزء من قيمتها مقابل انتقال ملكية تلك الأوراق المشتراة

ويتم تسديد تلك العمليات الحاضرة في حدود المدة المتعارف عليها لعملية

التسوية وهي حالياً يوم عمل بالإضافة إلي يوم التتفيذ ، وهو ما بطلق عليه ( T 1+) فالوسيط في تلك العمليات الحاضرة يحتاج إلي ذلك الوقت كي بسنطيع استكمال إجراءات نقل ملكية الأوراق المالية .

(1) وتسمي كذلك ، عمليات البورصة العاجلة مشار إلبه هامش (1) دم عبد الفضيل محمد :

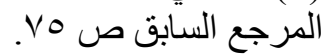

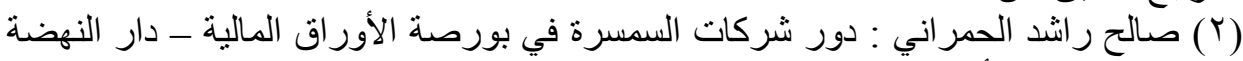

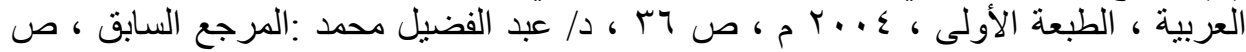

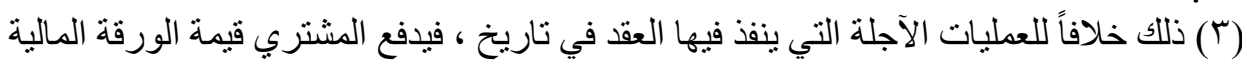

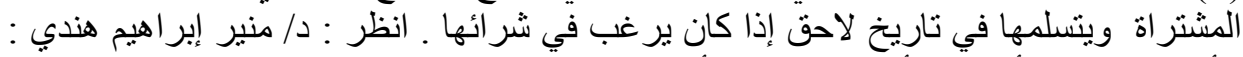

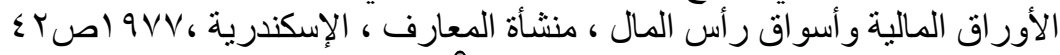


والعمليات الحاضرة في سوق الأوراق المالية غالباً ما تكون من أجل توظيف

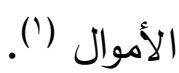

ولا يقصد فيها المشتري المضاربة المتعارف عليها في أسواق الأوراق المالية ،

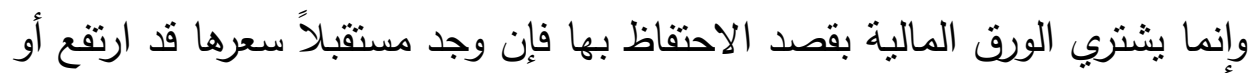

ربما فكر في بيعها والاستفادة بفارق السعر ، وبالتالي يكون العمل بالنسبة له

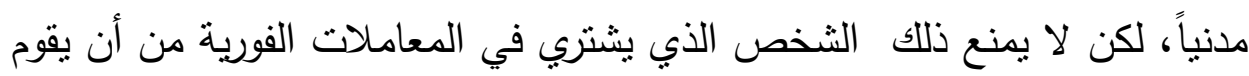

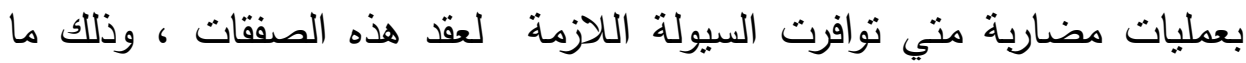
يجعله في مركز التاجر الذي يقوم بإبرام صفقات شراء المنقول بقصد إعادة البيع ، وتكون عمليات البيع والثراء في هذه الحالة حاضرة وفورية تتم بمبادلة الأوراق المالية بالثمن علي الفور وقت التعاقد ، وقد يتراخى الميعاد فترة وجيزة تحتاجها شركة السمسرة لاستلام النقود والأوراق المالية وتلك الفترة المتعارف عليها لا تعد

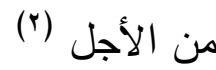

\section{وعمليات البورصة الحاضرة غير قابلة للرجوع فيها (") .}

والأصل أن يكون الغرض من عقد هذه العمليات بالنسبة للبائع الحصول

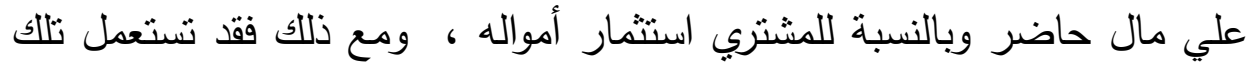
العمليات للمضاربة ، بأن يستقيد كل من البائع والمشتري من عملية فروق

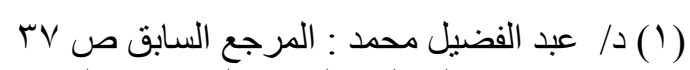

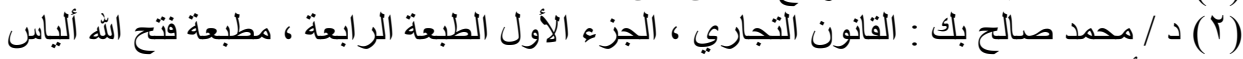

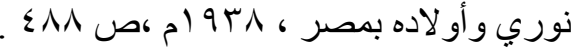

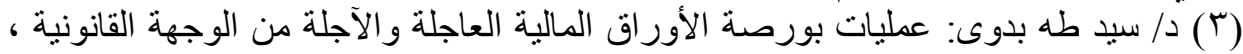

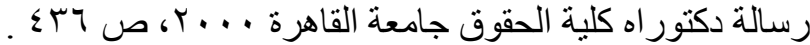


الأسعار ، ومعظم عمليات المضاربة عمليات آجلة(') . وعمليات البورصة الحاضرة ترد علي أي قدر من الأوراق المالية ، وهذا ما نصت علية اللائحة التتفيذية من قانون سوق رأس المال، والتي نصت علي أنه "يجوز التعامل علي أب عدد من الأوراق المالية ويكون سعر التداول للورقة المالية هو آخر سعر تم تتفيذ عملية به خلال يوم العمل محسوباً علي أساس متوسط الأسعار مرجحاً بالكميات ، وذلك علي كميات لا تقل من مائة ورقة ، ويكون سعر الإقفال للورقة هو السعر محسوباً علي أساس متوسط الأسعار مرجحاً به لكميات في نهاية يوم العمل علي ألا تقل الكميات علي مائة ورقة(؟) .

والعمليات الحاضرة (العاجلة ) هي التي يتم تتفيذها في سوق الأوراق المالية علي أصول مالية تمثل حقوق لأصحاب المشروع علي أصوله المادية ، تتحدد أسعار الصفقات من خلال آليات التسعير في السوق سواء من أعلي سعر يعرضه المشتري أوأدني سعر يقبله البائع (َ) . وتعتبر عمليات البورصة الحاضرة هي الصورة الأصلية لعقود البيع ، حيث يتم فيها نسليم الأوراق المالية مع الوفاء بالثمن عند التعاقد ويطلق عليها عقد البيع الفوري (๕)

(1) د/ عبد الحكيم الرافعي : الاقتصاد السياسي ، الجزء الثاني ، مطبعة التأليف والترجمة

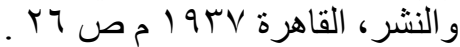

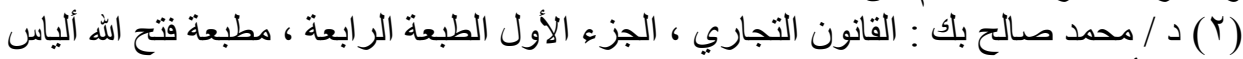

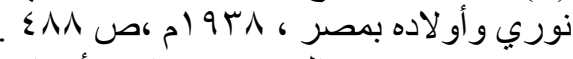

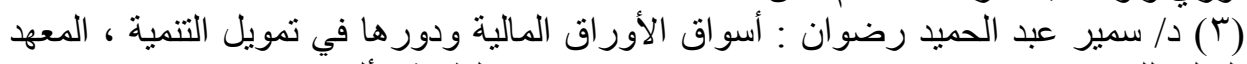

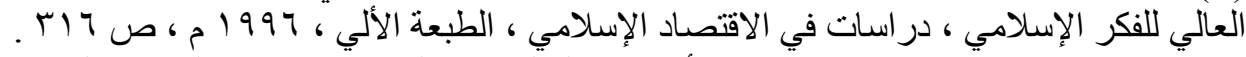

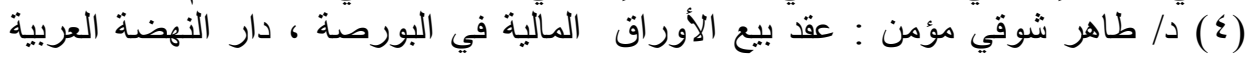
= 
وتعتبر عمليات البورصة المصرية في الغالب عمليات حاضرة وقد جاء

بقانون سوق رأس المال رقم 90 لسنة r99 199 م في المادة (•r) منه علي (أن تبين اللائحة التفيذية الأحكام المنظمة لعقد عمليات التداول والمقاصة والتسوية في عمليات الأوراق المالية ) وقد جاء باللائحة التنفيذية لقانون سوق رأس المال رقم 90 لسنة 199 19 م ( أنه لا يجوز للشركة تتفيذ أمر بيع أو شراء إلا بعد التأكد من وجود الورق المالية محل الأمر في حيازة البائع أو مودعة باسمه في نظام الحفظ المركزي وبعد التحقق من قدرة المشتري علي الوفاء بالثمن) ('). وقد جاء أيضاً باللائحة التتفيذية لقانون سوق رأس المال رقم 90 لسنة 199 1 أن يكون تتفيذ العمليات علي أساس التسليم مقابل سداد الثن وذلك بالنسبة للتعامل في السندات ) (r). والأصل في العمليات الحاضرة أن تتم من خلال تسليم البائع للأوراق المالية وقيام المشتري بسداد الثمن كاملا ، وهذا يعرف بمسمي التسليم مقابل الدفع ، إلا أن المشرع المصري قد خرج علي هذا الأصل وأجاز الشراء بالهامش استثناء علي التزام المشتري بسداد كامل الثنن أجاز اقتراض الأوراق المالية بغرض البيع (البيع علي المكثوف ) استثناءً علي التزام البائع بتسليم أوراق مالية مملوكة له بالكامل ، وفي جميع الأحوال نكون المبادلة حاضرة فورية ويتم تسويتها بنفس الطريقة التي بها تسوية عمليات التداول التي تتم علي أوراق مالية مملوكة للبائع مقابل قيام المشتري بدفع الثمن كاملاً وسوف نتتاول هذين النوعين بشئ من التفصيل كالآتي: 
أولاً: الشراء بالهامش ( Margin Buying )

طريقان تعرفهما الأسواق المالية لسداد ثمن الصفقات التي ثبرم بداخلها ، طريقة السداد النقدي الكامل ، وطريقة السداد النقدي الجزئي ، وأولي الطريقتين هي قيام العميل بسداد قيمة صفقاته نقداً وأن يحصل كذلك علي قيمة مبيعاته نقداً، وذللك كما هو متعارف عليه في سائر المعاملات العادية الطبيعية ، أما السداد النقدي الجزئي فيقصد به قيام العميل بسداد جزء من صفقاته نقداً والباقي يتم بأموال مقترضة ، بشرط ضمان الأوراق المالية محل الصفقة (؟) . والثراء بالهامش يتميز بأنه يؤدي إلي ارتفاع أحجام التداول بالسوق ، وذلك

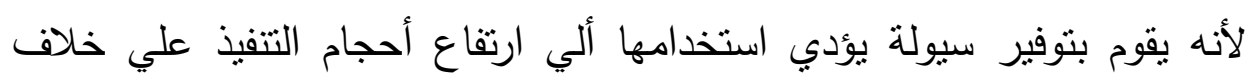
الأوقات التي لا يتم فيها الثراء بالهامش ، وهي غالباً ما تكون أيام ركود أو انكماش الأسواق في حالة هبوطها ، فنلاحظ أن أحجام التداول تقل تبعاً لذلك وهذا ما يعاني منه السوق المصري في الأونة الأخيرة، فالثراء بالهامش يتيح الفرصة لزيادة ومضاعفة الأرباح فهو يتيح للمستثر الذي بري فرصة مناسبة في ورقة مالية ما ، أن يقوم بشراء كميات أكبر من إمكانياته الحقيقية ، وبالتالي يتضاعف ربحه حتي بعد خصم العمولة الإضافية الخاصة بشركة السمسرة إن وجدت .

والشراء بالهامش نوع من المضاربة ، يلجأ اليه المشتري إذا توقع أن سعر الورقة المالية التي يرغب في شرائها سوف يرتفع في المستقبل ، فعند ذلك يقوم

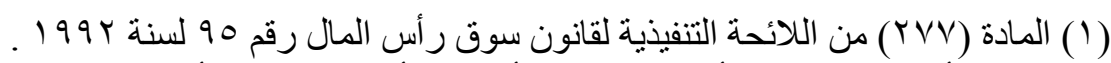

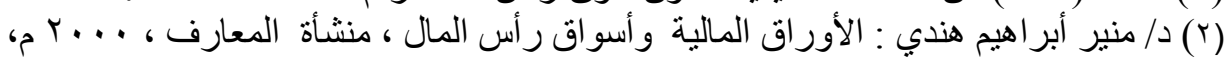

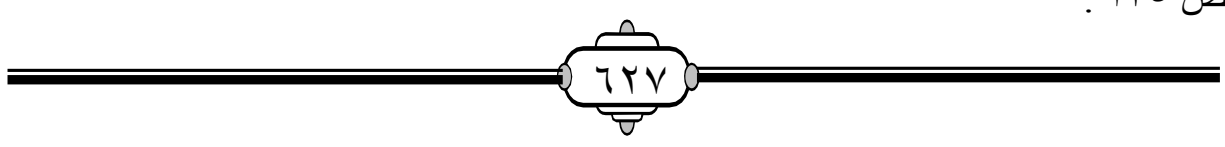




\section{عمليات البورصة واوامر العملاء بين القانون التجاري والفقه الإسلامي}

ببيعها ، فيتمكن من سداد قيمة القرض والفوائد بالإضافة إلي تحقيق مكاسب من

فرق السعر (') - (1) - (1)

ويعاب علي عمليات الشراء بالهامش تضخم الأسعار ، وارتفاع المؤشرات

نظراً لزيادة الطلب عن العرض ، فيجب أخذ ضمانات علي العملاء لدي شركات السمسرة ، ومنها رهن أوراقهم المالية حتي تضمن شركة السمسرة عودة رؤوس الأموال اليها ، وعلي ذلك يمكن في حال تطبيق الرهن ان تعطي شركة السمسرة الحق لنفسها في بيع تللك الأوراق المالية أو جزء منها اذا تعرض العميل لخسائر كبيرة مما تؤدي الي موجات بيع متتالية تؤثز سلباً علي السوق، وتتفاقم خسائر العميل في حالة دخوله في ورقة مالية معينة يأمل في ارتفاع سعرها، فيحدث عكس ذلك فهنا ستكون خسائره أكبر من الخسائر العادية حسب الهامش المعمول به مضافاً اليها خسارة العمولة المضاعفة المسحوبة عليه في نظام الثراء بالهامش (؟). وعملية الثراء بالهامش هي عملية تتم بموجب اتفاق بين ثلاثة اطراف ، : المقرض وهو أمين الحفظ ، وشركة السمسرة ، والعميل ، علي ان يقوم العميل بموجبه بسداد مبلغ نقدى لا يقل عن .0 في المائة من ثمن الأوراق المالية المشتراة لحسابه ، وبما لا يقل عن · ب في المائة بالنسبة للسندات الحكومية ما لم تحدد الهيئة نسبة سداد نقدى أخرى ، مع إنابة أمين الحفظ كتابة في إدارة حسابه من تلك الأوراق المالية بيعاً وشراءً في حالة إخلال العميل بالتزاماته ووفقاً لما تم

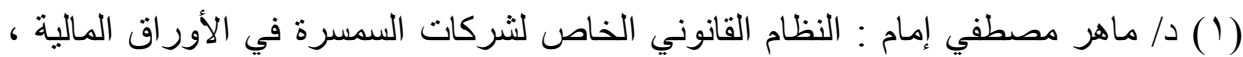

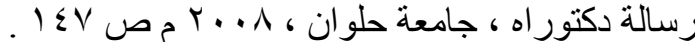

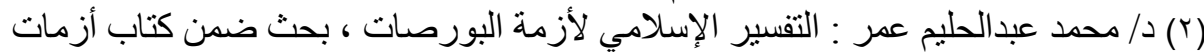

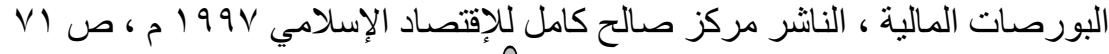


الاتفاق عليه بالعقد ، وتوفير التمويل اللزم لسداد جزء من ثمن الأوراق المالية المشتراة لحساب هذا العميل ، ويجوز للهيئة تعديل النسبة المذكورة في ضوء أوضاع السوق (') ع (1)

هذا وتلتزم شركة السمسرة وأمين الحفظ بأن يبرم اتفاقاً مكتوباً مع العميل الذي يرغب في شراء أوراق مالية بالهامش علي ان يتضمن هذا الاتفاق ما يلي : 1 - تحديد نوع الأوراق المالية التي تقوم الثركة بشرائها باسم العميل ونسبة السداد النقدى علي ألا تقل عن ـه في المائة ما لم تحدد الهيئة - بناءً على توصية من إدارة البورصة - نسبة سداد نقدى أخرى • r - قيمة المصاريف والعمولات ومقابل التكلفة للتمويل والمستحقة مقابل التعامل بالهامش والتي يجب على العميل سدادها والمدة اللازمة للسداد(؟). r - حق العميل في الوفاء بثمن الأوراق المالية في أي وقت . ع - تعهذ العميل بالسداد النقدي ، أو بتقديم الضمانات عند زيادة نسبة مديونيته الى القيمة السوقية للأوراق المالية محل الثراء من الحد المبين في المادة (79 ( ) من هذه اللائحة .

ه - موافقة العميل علي قيام امين الحفظ بتحميل حسابه يومياً بالمبالغ المستحقة له .

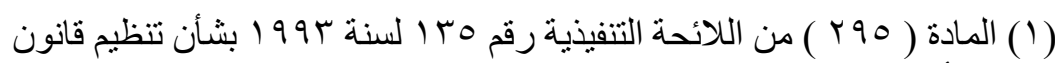

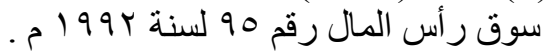

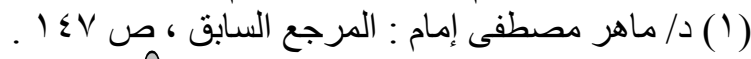


7 - توكيل العميل لأمين الحفظ في إدارة حسابه بيعاً وشراءً وذلك بالنسبة

للأوراق المالية محل الشراء بالهامش أو المقدمة كضمان وذلك في حالة إخلا العميل بالتزاماته . - موافقة العيل على قيام الهيئة والبورصة وشركة الإيداع بالاطلاع على حساباته من الاوراق المالية لدى أي جهة . ^ - جواز استرداد العميل لما يزيد من الضمانات المقدمة منه لأمين الحفظ اذا انخفضت نسبة مديونيته عن المتفق عليه . 9 - التزام العميل بأن يسلم الأوراق المالية التي يقدمها كضمان الي أمين الحفظ الذى أبرم معه الاتفاق اذا كانت هذه الأوراق مودعة لدى أمين حفظ أخر . • 1 - إقرار من العميل بإلمامه بكافة مخاطر التعامل بالهامش ، وعلى أمين الحفظ موافاة الهيئة بنموذج الاتفاق ، وللهيئة إدخال التعديلات اللازمة على هذا

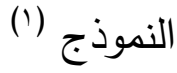

ثانياً : اقتراض الأوراق المالية بغرض البيع ( البيع على المكثوف ) البيع على المكثوف هو أن يقوم العميل ببيع أوراق مالية غير مملوكة له وقت صدور أمر البيع ، على أن يقوم باقتراضها وتسليمها للمشترى (؟) . وهذا على خلاف الأصل في المعاملات وهو أن يقوم العميل بشراء الورقة المالية أولاً ثم يقوم ببيعها بعد ذلك ، وهذا هو السلوك المنطقي للعميل المستثر الذي يتوقع ارتفاع القيمة السوقية للورقة المالية التي قام بشرائها ـ

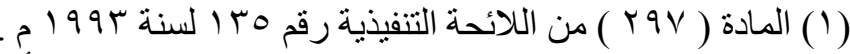

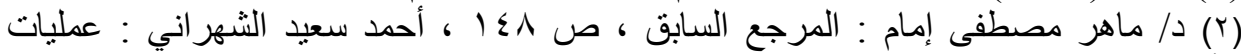

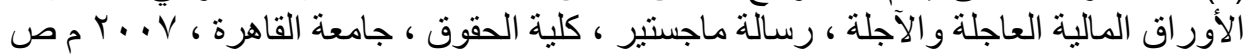

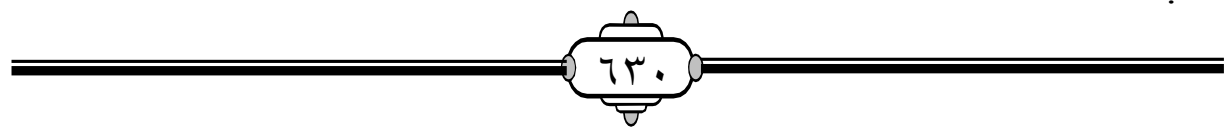


ويلجأ المستثر الى هذا النوع من المعاملات وهو البيع على المكثوف اذا ما توقع هبوط سعر ورقة مالية معينة ، حيث يقوم ببيع تلك الورقة المالية أولاً ثم يقوم بشرائها بعد ذلك عندما تتخفض قيمتها السوقية عن سعر الشراء (') وقد عرف البعض البيع على المكثوف بأنه عملية يقوم فيها العميل المضارب ببيع أوراق مالية غير مملوكة له وقت إصدار أمر البيع حيث يقوم باقتراضها من شركة السمسرة يوم تتفيذ العملية كويقوم بتسليمها الى المشترى وتقوم شركة السمسرة بالاحتفاظ بالثمن لديها على أمل أن تتخفض أسعار الورقة المالية فتتنربها شركة السمسرة لحساب العميل وتعيدها الى مالكها الأصلي ويحصل على الفرق بين سعر البيع وسعر الثراء كما يحصل السمسار على عمولة عملية البيع وعلى فائدة عن القرض(؟) وتعتبر تلك الصورة من من العمليات عملية مضاربة على هبوط الأسعار ، وعادة ما يقوم العميل بدفع تأمين لشركة السمسرة لضمان تغطية الفرق في الأسعار فيما لو زادت تلك الأسعار ، وهذه الآلية طالما نادى بها المستثمرون في البورصة المصرية كي يتم تطبيقها ولكن لا أحد يجيب ، والواقع العملي أثبت صعوبة إجراء منل تللك العمليات إلا اذا كانت شركة مصر للمقاصة والتسوية قد أدخلت أحدث التقنيات لأمور التسوية والإيداع والحفظ ، وعند حدوث ذلك سوف يستقيد السوق المصري من أهم إحدى الأليات التي غابت عنه طويلاً وهى آلية الاقتراض بغرض البيع والتي تعتبر مقابلاً قوياً لآلية الثراء والبع في ذات الجلسة ( t+0)

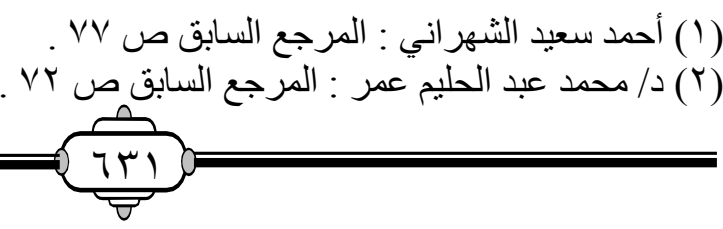


والذى يتم اللجوء اليه في الأوقات التي يتوقع فيها المستثرون ارتفاع الأسعار بخلاف حالتتا(') تلك وهى الاقتراض بغرض البيع فالتوقع بهبوط الأسعار وليس

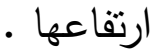

والعميل في عملية الاقتراض بغرض البيع يبيع ما لا يملك وقت إصدار أمر البيع (r) . وهو معرض لمخاطر ارتفاع الأسعار بخلاف تحمله لفائدة القرض ك. والتوسع في إجراء عملية البيع على المكثوف في ورقة مالية معينة له آثار سلبية على سوق رأس المال ، لأن زيادة استخدامه في ورقة مالية بعينها يوحى لباقى المستثمرين الآخرين الذين يحملون في محافظهم تلك الورقة بأن سعرها سوف ينخفض وتتخفض قيمتها السوقية وبالتالي هناك أخبار سلبية في مقومات الشركة ، أو مركزها المالى، أو عدم تحقيقها أرباح على خلاف الحقيقة، وبالتالي يتخارجون منها بالبيع ، وهذا أمر يضعف كفاءة سوق رأس المال (r) . . ويعتبر البيع على له المكثوف من عمليات البورصة الحاضرة لأن العميل ملزم بتسليم الأوراق المالية التي باعها الى العميل الذى قام بشرائها منه (ء) وصورة البيع على المكثوف أن يتم اقتراض الأوراق المالية المراد التعامل عليها قبل بيعها ، على أن يتم بيعها بسعر يزيد على الأقل بوحدة واحدة على سعر الإقفال في بداية الجلسة أو آخر سعر تداول أثثاء الجلسة ، ويجب أن يكون الاتفاق على الاقتراض بغرض البيع مكتوباً ، وأن يتضمن نوع الورقة المالية

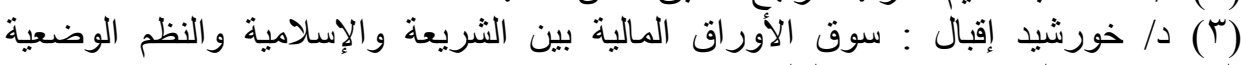

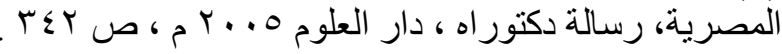

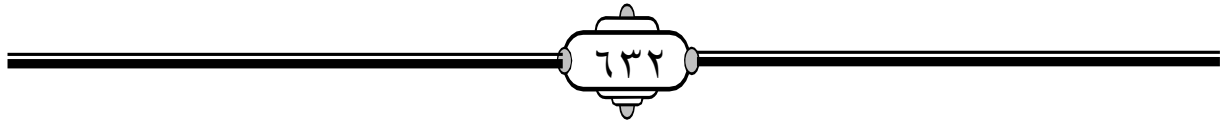


المقترضة ، ومدة الاتفاق ، ومقابل اتفاق القرض ، وألا يقل الضمان النقدي عن • 0 في المائة من القيمة السوقية للأوراق المالية المقترضة قبل إتمام العملية ، وجميع العمولات والمصروفات التي يتقاضاها أمين الحفظ بالتقييم اليومي للأوراق المالية محل الاتفاق ، واستقطاع ما يعادل قيمة الحقوق المالية والمزايا الأخرى التي تتتجها الورقة المالية المقترضة في تاريخ استحقاقها من حساب المقترض لصالح حساب المقرض ، ما لم يتم الاتفاق على غير ذللك في اتفاق القرض وبموافقة المقرض وحالات انهاء الاتفاق والآثار المترتبة عليه ، وتقدير الضمانات المقدمة من المقترض وحالات طلب ضمانات إضافية (') . وعلى أمين الحفظ ان يقوم بتقييم في نهاية كل يوم عمل للأوراق المالية 7. المقترضة وفقاً لقيمتها السوقية ، فإذا رأى أمين الحفظ أن المديونية تجاوزت في المائة من قيمتها السوقية بسعر الإقفال محتسباً على أساس المتوسط المرجح وجب عليه إخطار العميل لتخفيض نسبة المديونية بالسداد النقدي وتكون هذه النسبة 10 في المائة للسندات الحكومية ، وفى جميع الأحوال يقوم أمين الحفظ باتخاذ إجراءات شراء الأوراق المالية المقترضة اذا بلغة نسبة المديونية • V في المائة من قيمتها السوقية ويجوز للهيئة تعديل النسب المشار اليها وفقاً لأوضاع

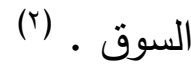

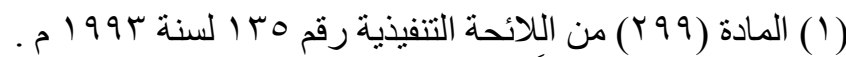

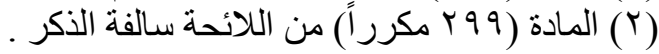

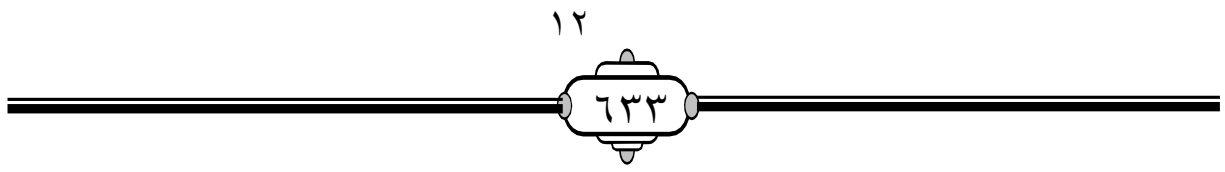




\section{الفرع الثاني \\ العمليات الآجلة في البورصة}

العمليات الآجلة ويطلق عليها عقود الاختيار ، وهى عباره عن العمليات التي

يتفق فيها الطرفان البائع والمشترى على تأجيل تشليم المقابل ( الثن ) اذا كان مشترياً والأوراق المالية اذا كان بائعاً الى يوم محدد متفق عليه مسبقاً يطلق عليه يوم التسوية أو يوم التصفية ، بحيث يتم تسوية هذه العمليات بمجرد دفع الفرق في السعر بين السعر المتقق عليه والسعر المحدد في يوم التصفية . .

وقيل في تعريفها هي العمليات التي يتراخى تتفيذها الى تاريخ لاحق يعرف بيوم التصفية ، ويتحدد يوم التصفية في نهاية الثهر الذى تم فيه الاتفاق بشروط محدة وفقاً للائحة عمليات البورصة الآجلة وهو تاريخ ثابت غير متغير ومحدد

بالجلسة السادسة في البورصة قبل نهاية الثهر الذى ثم فيه الاتفاق (') . وقد عرف جانب من الفقه العمليات الآجلة بأنها عبارة عن البيع الجزئي ، وهو عبارة عن مبلغ من النقود ، يتعهد البائع أو المشترى بسداده للطرف الآخر إذا رغب في عدم تتفيذ الصفقة ، وهذا المبلغ هو مقابل لحق النكول الذى يحدد خطر الناكل عند تتفيذ العقد في المبلغ الذى قام بدفعه(ז) . وتعد العمليات الآجلة الركيزة الأساسية في سوق الأوراق المالية ، وهى متتوعة ومختلفة من بورصة الى أخرى ، ومن بلد الى آخر ، فاذا تبايع الطرفان

(r) د / محمد صالح : شر ح القانون التجاري المصري ، مطبعة الاعتماد ، الطبعة الثالثة ،

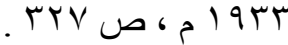
(1) صالح راثد الحمر اني : دور شركات السمسرة في بورصة الأوراق المالية ، دار النهضة

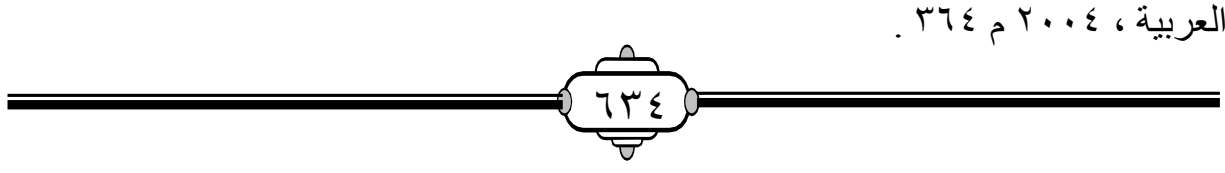


على أن يتم تأجيل التسليم ودفع الثمن الى يوم معين يتفقان عليه ، فإن ذلك البيع يعد من العمليات الآجلة . وقد كانت تلك العمليات باتة تتم وفق عقود رضائية(')، إلا أن بعض التجار كان يتراجع عن التتفيذ إذا رأى أن تتفيذ العقد في غير صالحه ، وهنا ظهرت العمليات الآجلة الشرطية (r). والعمليات الآجلة يوجد لها نوعان رئيسيان من العقود الأول منها عقود آجلة باتة لا يستطيع 'فيها أطراف العقد التحلل منها ، وبمعني آخر لا يكون فيها لأحد طرفي العقد حق النزول عنه والثاني منهما عقود آجلة شرطية تعطى صاحبها حق العدول عن العقد (r) (ب)

وهذا النوع بدوره ينقسم الى قسمين رئيسيين فيوجد فارق بين الأنظمة المختلفة في هذا النوع من العقود الآجلة ـ يرجع هذا الفارق الى أساس تتفيذ العقد في كل نظام. وتوجد ثلاتة أنواع من الخيارات للعمليات الآجلة هي : أولاً : خيار الشراء : n

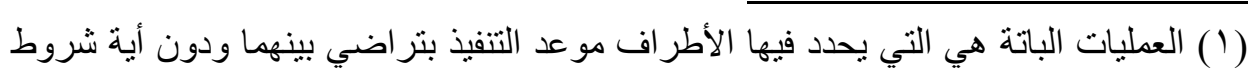

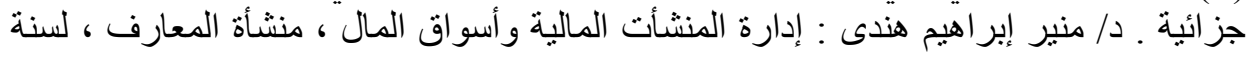

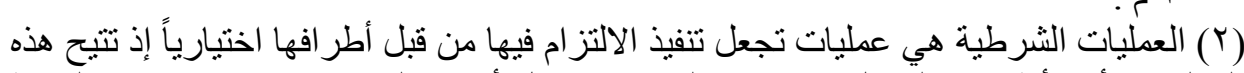

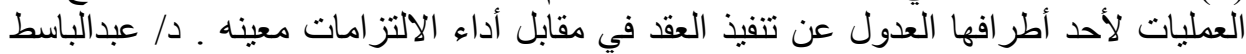

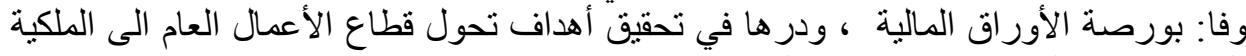

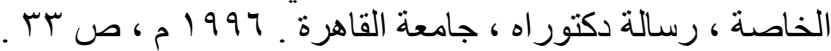

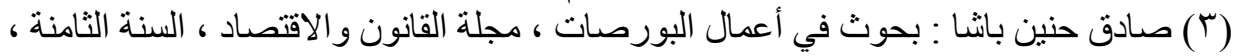

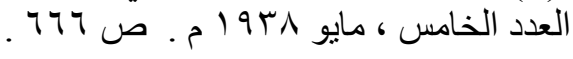

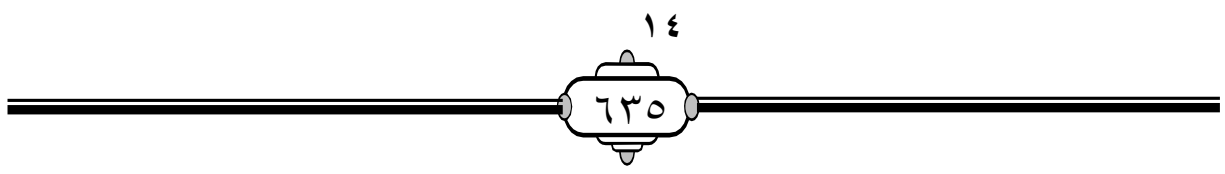


حق الخيار بالشراء هو حق يعطى لمشترى حق الإختيار شراء عدد من الأوراق المالية بسعر محدد هو سعر الممارسة في تاريخ محدد وهو تاريخ الإستحقاق ، وذللك كأن يشترى عميل حق شراء عدد ... . . سهم من أسهم شركة الحديد مثناً بسعر متفق عليه سلفاً .

وغالباً م ايكون هو سعر الأسهم وقت إبرام العقد - وليكن هذا السعر هو ه ه. جنيات للسهم بخلاف عمولة شركة السمسرة ، ويقوم المشترى بدفع مكافأة للبائع " محرر الاختيار "ولتكن هץ قرشاً للسهم .

وهنا تتفيذ منل هذا العقد لا يعدو عن أمرين ، الأول أن يرتفع سعر السهم موضوع عقد الاختيار في سوق التداول في تاريخ التفيذ ليصبح · 1 جنيهات للسهم ففي هذه الحالة لا يتردد مشترى حق الخيار في طلب تتفيذ العقد أو طلب التسوية النقدية والتي تقضى حصوله على فروق الأسعار وهى خمسة جنيهات عن كل سهم ، والأمر الثاني أن ينخفض سعر السهح موضوع عقد الخيار أو أن يبقى على سعره ، فهنا لا يكون لصاحب حق الثراء مصلحة في تتفيذ العقد ويكون قراره بعدم تتفيذ الحق ، وبكون دفعه لقيمة مكافأة الحق هي أقل الأضرار.

وبذللك نستطيع القول أن من يتوقع ارتفاع ورقة مالية معينة فإنه يبرم شراء حق خيار شراء ، ويمكنه من شراء تلاك الورقة المالية خلال فترة معينة هي مدة عقد الخيار ، أو فترة محدة يكون لمشنتري الخيار الحرية الكاملة في أن يمارس حقه في ممارسته دون أي التزام عليه ، وذللك مقابل ثمن يدفعه كمكافأة للطرف الأخر • وذلك مقابل التزام الطرف الآخر بتتفيذ العقد بالسعر المتقق عليه وفي المدة المحددة لمشتري الخيار لممارسة هذا الحق.

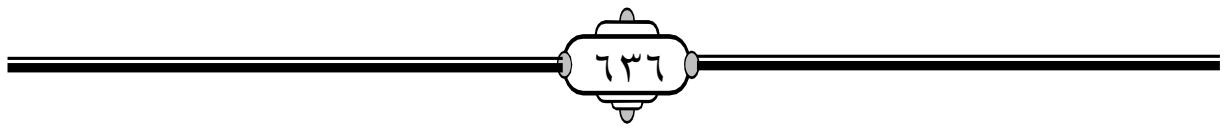


ثانيا: خيار البيع:

هو علي خلاف خيار الثراء ويعطي حق العدول للبائع عن بيع الكمية المعينة من الأوراق المالية وتتحدد مسئوليته في المبلغ المدفوع (') . فيشتري خيار البيع الذي يتوقع انخفاض سعر ورقة مالية معينة فهو يقبل عقد هذه الصفة لأنه يضارب علي انخفاض سعر الورقة المالية موضوع عقد الخيار فكلما صحت توقعاته وانخفض سعر الورقة المالية زادت أرباحه ، وإذا لم تتحقق توقعاته كأن ارتفع السعر فهنا بائع الخيار يتعرض للخطر ، ألا أنه يفضل شراء حق الخيار نكون خسائره محدودة بمقدار قيمة المكافأة المحددة ثمناً لهذا الخيار ، وذلك لأن خيار البيع التزاما علي مشتري حق خيار البيع (؟). وخيار الثراء وخيار البيع لا يمثلان في الواقع لا شراء فعليا ولا بيعا فعليا

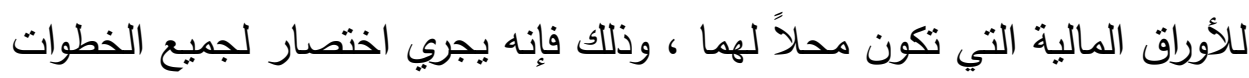
التي تتم في السوق الحاضرة والمتعلقة بنقل الملكية ويستعاض عن ذللك بالتسوية والمقاصة النقدية .

\section{ثالثاً : حق الخيار المزدوج :}

هو حق يلجأ إليه المضاربون كي يتجنبوا المخاطر إذا ما قاموا بإبرام أحد الحقين السابقين وطرأت علي السوق تغيرات قد تمنيهم بخسائر كبيرة .وفي هذا الخيار يقوم المستثر بشراء حق خيار شراء وحق خيار بيع في نفس الوقت

ولنفس الورقة المالية في تاريخ واحد للحقين وتاريخ واحد للانتهاء (־) .

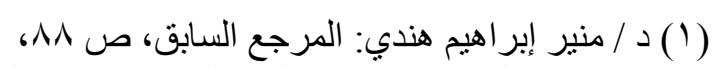

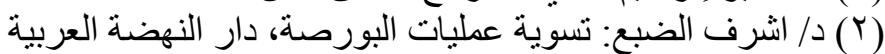

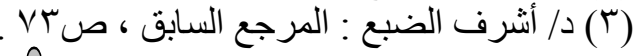




\section{عمليات البورصة وأوامر العملاء بين القانون التجاري والفقه الإسلامي}

وقد مرت العمليات الآجلة بمراحل متعددة في البورصة المصرية بين جوازها وعدم جوازها وقد جاء قانون سوق رأس المال خلواً من أي إثارة بشأن تلك العمليات الآجلة ومدي جوازها في البورصة المصرية من عدمه إلي أن جاء قانون التجارة الجديد رقم V لسنة 1999 م في • المادة (7؟) من القانون التجارة الجديدة الجديد رقم VI لسنة 1999 نتص علي أن " تكون العمليات المضافة ألي أجل صحيحة ولو قصد المتعاقدون منها أن نؤول ألي مجرد التزام بدفع فروق الأسعار بشرط أن تعقد العمليات في سوق الأوراق أن تتعلق بصكوك مدرجة في أسعار هذا السوق ويصدر بتتظيم هذا العمليات قرار من الوزير المختص " . المادة 7 ك منه ونص علي صحة العمليات الآجلة في البوصة المصرية بشرط أن تتم داخل سوق الأوراق المالية وتكون تلك الأوراق مقيدة في البورصة(') . 
المطلب الثاني

\section{أوامر العملاء لشركة السمسرة}

نظراً لأن أعمال التداول بالبورصة أصحبت حكرا على سماسرة الأوراق المالية. فلا يجوز للفرد العادي القيام بها في في جميع بورصات العالم • ومن ثم فإنهم يتطلبون تفويضا ممن لله الحق في التداول وهم العملاء وهم العملاء للقيام بهذا المهمة وبتعربف بسيط لأوامر البورصة نستطيع القوال بأنها التعليمات الصادرة من العميل ألي شركة السمرة ببيع أو شراء الأوراق المالية وفقاً لشروط خاصة ـ فأوامر البيع ، والذي يعتبر بمثابة الإيجاب ، وتمثل إدارة المشتري بأوامر الثراء، والذي يعتبر بمثابة القبول ، وبحدوث تلاقي الإرادتين ينعقد عقد بيع الأوراق المالية وسوف أتعرض في ذلك المبحث لماهية أوامر البورصة ثم أنواع أوامر البوصة كلُ في فرع مستقل علي النحو التالي :

الفرع الأول : ماهية أوامر البورصة . الفرع الثاني : أنواع أوامر البورصة . 


\section{الفرع الأول}

\section{ماهية أوامر البورصة}

نقطة البدء في عمليات البورصة هي صدور أمر من العميل إلي شركة السمرة التي يقوم باختيارها ، يخطرها فيه برغبته في أجراء عملية معينة من عمليات البورصة. ويسمي الأمر "أمر شراء " إن كان صادراً عن العميل في رغبته في شراء ورقة ماليه معينة و "أمر بيع" إن كان صادراً عن العميل في رغبته في البيع

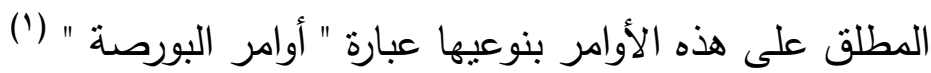

وعملية البورصة ما هي إلا عقد بيع علي قيم منقولة كالأشياء المنلية .

وتتسلم شركة السمسرة أمر البورصة من عميلها ثم تقوم بتنفيذه حيث أن

عمليات البورصة لا تتم مباشرة بين البائع والمشتري • بل تتم عن طريق تذخل الوسطاء شركة السمسرة (). فيخضع تتفيذ أوامر البورصة لامتياز قرره المشرع لشركات السمسرة في الأوراق المالية دون غيرها .ومن هنا كان الأمر هامأ فيما يتعلق بتلك الأوامر

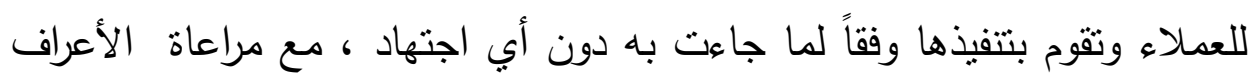

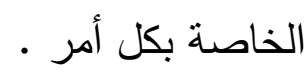
والمشرع المصري في قانون راس المال رقم 90 لسنة ب99 ام ولائحته التنفيذية رقم هبا لسنة بو99 19 م(ז) ولم يلزم العميل بأن يصدر أمر وفق شكل

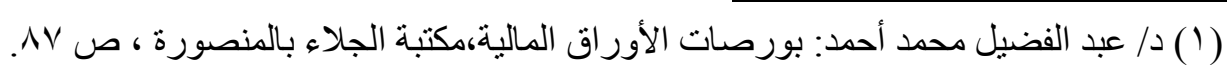

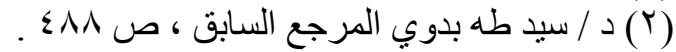

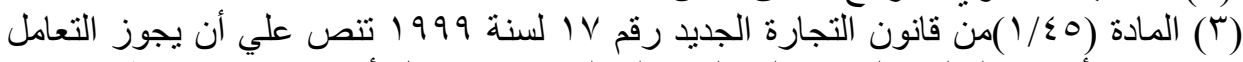

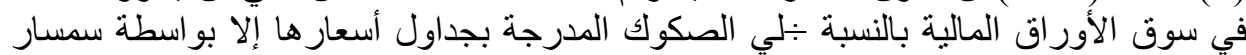
مقبول للتعامل بها ألا كان التصرف بالنبة باطلًا.

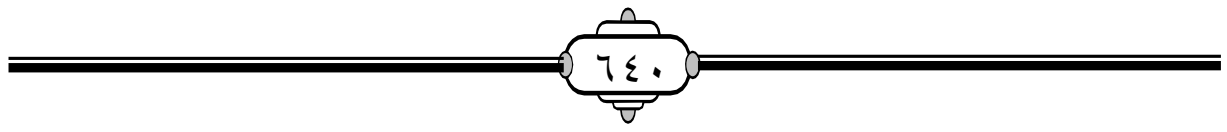


معين فقد يصدره شفوياً ، أو مكتوباً ، أو بواسطة التليفون، أو الفاكس، أو التليكس، أو بوسائل التكنولوجيا الحديثة كالبريد الالكتروني ، أو الإنترنت، فالأمر تعبير عن

إرادة العميل (1)

وقد يقوم العميل الحصيف بطلب تعزيز الامر بورقة مكتوبة حتى يتمكن من إثبات الأمر بسهولة عند حدوث أي نزاع بينة وبين شركة السمسرة.

والمشرع في ذلك راعي أن أوامر البورصة هي من البيوع التجارية وهي من العقود الرضائية التي تتم بمجرد الإيجاب والقبول. وإن كان ذلك هو الأصل وما يجري عليه العمل في البورصات العالمية إلا أن المشرع المصري في قانون التجارة الجديد رقم V V لسنة 1999 م قد جاء بحكم مفاده أن أوامر البوصة يجب أن تكون مكتوبة فنص على أن لا يجوز للسمسار إجراء عمليات في السوق لحساب عملائه ألا أذا كان مفوضاً في أجرائها من العميل بموجب تفويض خاص مكتوب، فإذا أجري السمسار العملية دون هذا التفويض جاز للعميل قبولها أو رفضها (ץ) . ثم جاءت اللائحة التنفيذية لقانون سوق رأس المال ونصت على أن (ويجوز للشركة أخذ أوامر عملائها هاتفيا وفقاً لنظام تسجيل موافقة العميل كتابة) (َ). فهنا في اللائحة التنفيذية لقانون سوق راس المال نجد المشرع تطلب أن يوافق العميل كتابة علي نظام التسجيل دون غيره، وأجازت تلقي الأوامر بجميع أنواع الاتصال. أما بالنسبة لقانون التجارة الجديد فقد تطلب الكتابة لتتفيذ الصفقة فإذا لم يكن بأمر كتابي كان العقد قابلاً للفسخ لمصلحة العميل الذي له أن يقبله، أو

(1) د/ عبد الفضيل محمد : المرجع السابق ص NV ،صالح ر اشد الحمر اني : المرجع السابق ص Trt

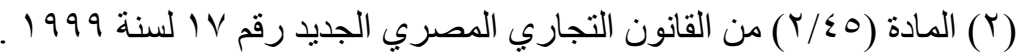

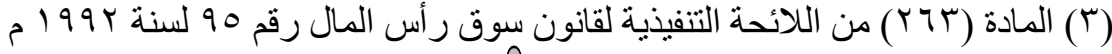


يرفضه، ويحب أن يصدر الأمر من ماللك الورقة المالية، كما يجب أن يصدر إلى من لله الصفة القانونية وهو في مصر شركات السمسرة وفقاً لما نص عليه قانون

سوق رأس المال (1) - من ل)

وأوامر البورصة باعتبارها تعبيرا عن إرادة العميل الأمر • يلزم فيها أن تكون

صادرة عن شخص ثتوافر فيه الأهلية ، فلا يكون أمر البورصة صحيحاً إذا صدر من شخص عديم الأهلية أو كان رضاؤه معيباً أو منقوصاً من أهليته ، وكذلك تتحقق من صفته إذا كان يتصرف لحساب شخص آخر ، وخصوصاً إذا كان هذا

العميل غير معروف شخصياً لدي شركة السمسرة وموظفيها (؟).

كذلك لابد وأن يكون أمر العميل واضحاً ومحدداً تحديداً كافياً حتى تسنطيع شركة السمسرة أن تتفذه دون خطاً. ومن أجل ذلك يلزم أن يكون الأمر متضمناً لطبيعة العملية بيعاً أم شراءً والصك المراد التعامل بثأنه من حيث طبيعته، سهماً أم سنداً أم حصة نأسيس أم صك تمويل. وكذلك نوعه كأن يكون عادياً أو ممتازاً والعدد المراد شراؤه أو بيعه. وكذلك السعر الذي يرغب العميل أن يتعامل به والتاريخ والتوقيع، متي كان أمر البورصة قد صدر كتابة من العميل (') وما يجري عليه العمل في سوق رأس المال المصري هو أن يقوم العميل بإصدار أوامره ألي شركة السمسرة سواء كانت تلك الأوامر

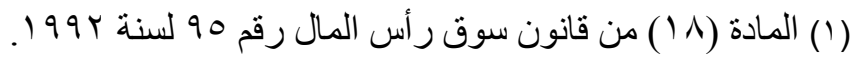

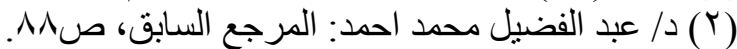

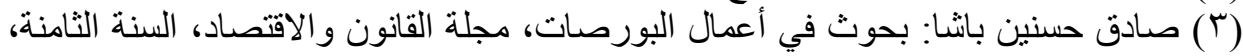

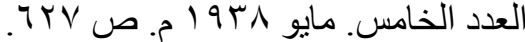

$r$.

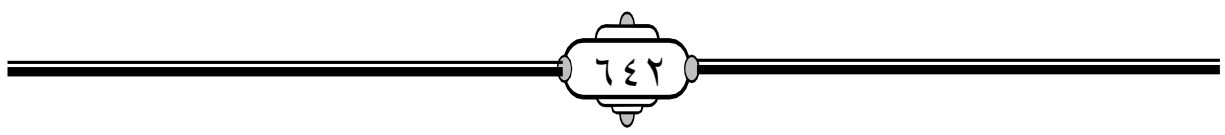


كتابية أم هاتقية، ثم تقوم شركة السمرة بتسجيل تلك الأوامر في سجل خاص، بعد أن تتأكد من وجود الرصبد النقدي في حالة الثراء.

أو الورقة المالية في حالة أوامر البيع ثم تسلمها إلي مندوب الثركة في البورصة، والذي يمسك سجلا مماثلا لسجل الثركة به ذات البيانات عن الأوامر فيقوم بإدخالها في الحاسب الآلي المتصل بالبورصة، ولا يجوز لمندوب الثركة أن يتلقي مباشرة من العملاء أوامر البيع أو الشراء، كما لا يجوز تتفيذ أي عملية غير مقيدة بسجل أوامر العملاء بشركة السمسرة (') .

وإذا كان القانون قد أباح لشركات السمسرة تلقي أوامر العملاء هاتفياً فيجب

على شركات السمسرة أن نوفر الوسائل اللازمة لمباشرة نشاطها (؟). ولا يجوز لثركة السمسرة أن تمتتع عن تلقي أوامر العملاء سواء كان الامتتاع أو إهمالاً.

وقد نصت اللائحة التنفيذية لقانون سوق رأس المال على أن " لا يجوز للشركة أن تحجم عمداً عن عرض أو طلب الأوراق المالية بيعاً أو شراء من أجل تحريك أسعارها أو أن تتفق مع أي طرف على القيام بعمليات توحي بوجود عرض أو طلب على الأوراق " (") . ونص تلك المادة يحذر شركات السمسرة من الإحجام العمدي فقط دون غيره وكان أحري بالمشرع أن يجعل النص يشمل الإحجام بوجه عام عمداً وذلك لما

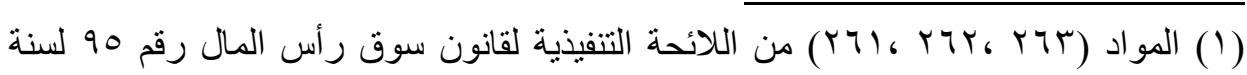

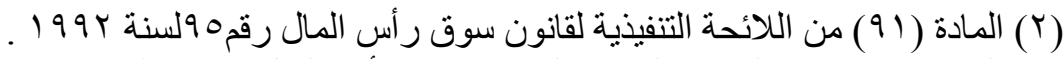

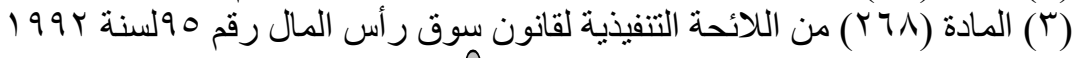


لهذه من أهمية لأن مضاربات شركات السمسرة تجعلها تتحين الفرصة في منل تلك النصوص الغير دقيقة، ونستخدم هذا الخلل لصالحها.

ومما تجدر الإشارة إلبه هنا أن أزمة البورصات العالمية في أكتوبر IANV م أحدثت أضراراً جسيمة بسبب أن السماسرة وهم صناع السوق لم يردوا علي مكالمات العملاء وتلقي أوامرهم الصادرة ألي شركات السمرة (') . وقد نص المشرع في اللائحة التنفيذية لقانون راس المال رقم 90 لسنة ب99 م علي أن يحب علي الثركة السمسرة تسجيل أوامر العملاء فور ورودها إليها ، وبثمن التسجيل مضمون الأمر واسم مصدره وصفته وساعته وكيفية وروده الى الثركة، والثمن الذى يرغب العميل التعامل به (ז) ويجب ان يكون وقت تتفيذ أمر البورصة محدداً سواء كان يوماً أو أسبوعاً أو شهراً وعلى شركة السمسرة تتفيذه خلال تلك المدة واذا انقضت المدة دون تتفيذ اعتبر الأمر لا غيا، واذا قام السمسار بتتفيذ الأمر خلال مدة الصلاحية كانت العملية صحيحة منتجة لأثارها ، حتي ولو مات العميل مصدر الأمر دون علم السمسار ، ويترتب علي ذلك التزام ورثة العميل بنتائج الأمر الذى أصدره مورثهم (") . فإذا لم يقم العمبل بتحديد وقت لتتفيذ الأمر الصادر منه لشركة السمسرة فهنا يجب على شركة السمسرة عرض الأمر في أول جلسة نالية لوروده كما داء في نصوص اللأحة التتفيذية لقانون سوق رأس المال (£)

(1) د/ منير إبر اهيم هندي : بحث في أزمة البورصات العالمية ، مركز صالح كامل للاقتصاد

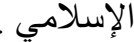
(1) (1) المأدة (7) (97) من لائحة قانون سوق رأس المال

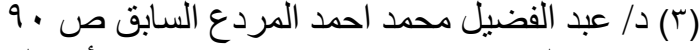

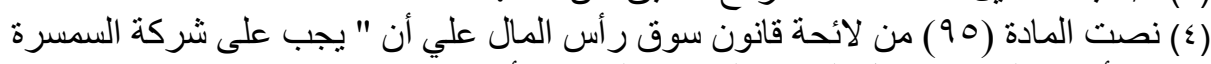

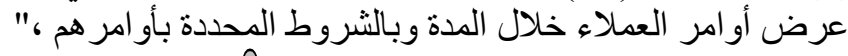


ويحق للعميل الذى أصدر لشركة السمسرة أمرا بالبيع أو الشراء ان يلغى هذا الأمر بعد إصداره ، طالما أنه لم ينفذ بعد ، أو أن يقوم بتعديله فيعدل السعر مثلاً أو عدد الصكوك محل الأمر ، ولكن هذا الإلغاء من قبل العميل لا يسرى في حق شركة السمسرة إلا من تاريخ إبلاغها به وقبل افتتاح جلسة البورصة المزمع تتفيذ

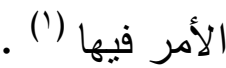

إلا أننى أرى أن العميل بستطيع تعديل الأمر أو إلغاؤه أثناء جلسة التداول طالما كان ذلك ممكناً 'َويوجد وقت كافٍ لشركة السمسرة كي تقوم بتنفيذ الأمر بالإلغاء أو التعديل وذلك لأن الجلسة في الوقت وتتتهى الساعة الثانية ونصف ظهراً طوال أيام الأسبوع ما عدا الجمعة والسبت وأيام العطلات الرسمية ، تسبقها جلسة استكثافية تبدأ من الساعة التاسعة ونصف صباحاً وحتى العاشرة إلا خمس دقائق ، تستطيع شركات السمرة من خلال منفذيها أن تتلقى الأوامر الصادرة من العملاء وتبلغها لمنفذيها كي يقوموا بإدخالها ضمن العروض والطلبات للأوراق المالية، فهنالك أوراق مالية تعمل بنظام 0 \% صعوداً وهبوطاً لا تتعداها ، وهناك أوراق مالية تعمل بنظام • ( معوداً وهبوطاً ، وذلك وفقاً لما أذا كانت الورقة المالية تتتمى الى المؤشرات الرئيسية أو مؤشر بورصة النيل للشركات الصغيرة والمتوسطة ومع وجود التقنيات الحديثة لاى شركات السمسرة من وسائل اتصال بينها وبين عملائها يستطيع العميل تبليغ تعديل أو إلغاء الأمر لشركة السمسرة في أقل من دقيقة وهى تستطيع أدخال ذلك التعديل أو الإلغاء في أقل من ذلك .

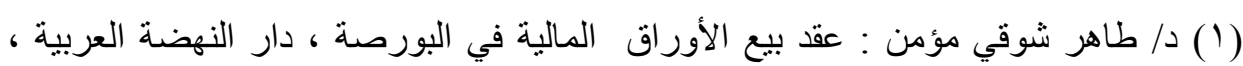

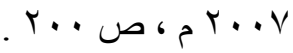

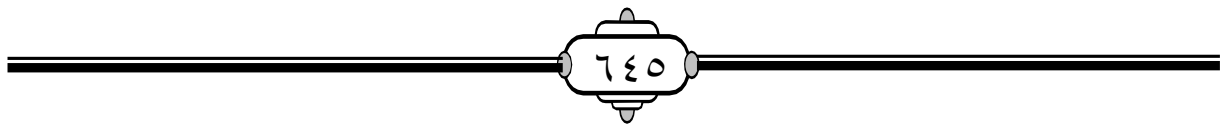


ولا تستطيع شركة السمسرة أن تلغى او تعدل الأمر الصادر اليها من العميل من تلقاء نفسها . حيث أنها ملتزمة بعدم تجاوز حدود وكالتها ، وإلا قامت مسؤوليتها متى لحق بالعميل ضرر من ذلك (') .

وكذلك فان شركة السمسرة ملتزمة بتتفيذ أوامر العملاء وفى حدودها (r) وفقاً لنص اللائحة التتفيذية لقانون سوق رأس المال حيث نصت على أن " تلتزم الثركة بتتفيذ أوامر العملاء في الحدود الصادرة بها ولا يجوز لها أن تتجاوز هذه الحدود عند بيع أو شراء الأوراق المالية ويحظر عليها تتفيذ العمليات بأسعار أو بكميات تتجاوز أوامر العملاء بالزيادة أو بالنقص (ז) . وما نصت عليه أيضاً من أن تلتزم شركة السمسرة التي نفذت عملية على خلاف أوامر العميل .... بتسليم ورقة غيرها

خلا أسبوع من تاريخ المطالبة وإلا وجب عليها تعويض العميل (\&)

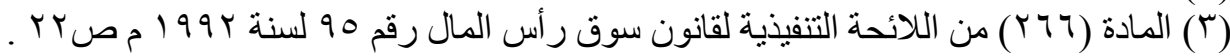

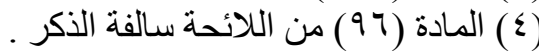




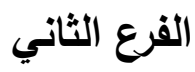 \\ أنواع أوامر البورصة}

أوامر البورصة لها أنواع متعددة وذلك يتحدد وفقاً لرغبة العميل مصدر الأمر : العر لشركة السمسرة ، فقد تكون رغبة العميل أن يتم تتفيذ أمره الصادر بالبيع أو الثراء بسعر معين ، أو وقت محدد يتتاسب مع ظروفه المالية ، ومدى ملائمة هذا التتفيذ لتلك الظروف ، وقد تكون رغبة العميل في تتفيذ أمره الصادر لثركة السمسرة وفق ما يراه السمسار ، فأوامر البورصة تختلف طبيعتها باختلاف درجة المخاطر لكل عميل وطبيعة كل صفقة ، وهى مسألة نسبية تختلف من عميل لآخر ، وسوف أنتاول أنواع الأوامر في أربعة أنواع لتلك الأوامر على النحو التالي :

\section{النوع الأول : الأوامر المحدة لسعر التنفيذ}

الأوامر المحددة لسعر التنفيذ يقصد بها ذلك النوع من الأوامر التي يكون السعر فيها هو الفيصل في تتفيذ الصفقة من عدمه (') . وهى الأوامر التي يطلب العميل فيها من شركة السمسرة أن تتفذ له بسعر محدد أو بأفضل سعر في السوق فهي بالتالي نتمل نوعين من الأوامر أوامر السوق والأوامر المحددة وهى التي

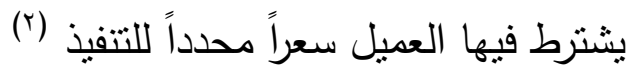

$$
\text { أولاً : أوامر السوق }
$$

أوامر سعر السوق يطلق عليها ايضاً الأوامر بأحسن ما يكون ، أو الأوامر بأفضل الأسعار • وتعتبر تلك الأوامر من اكثر الأوامر شيوعاً بين العملاء نظراً لما

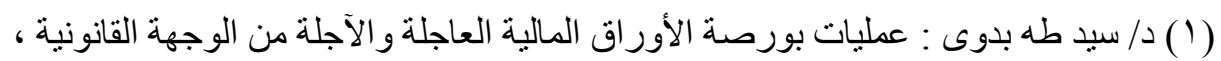

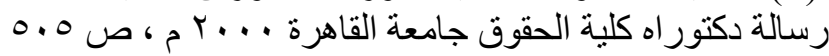

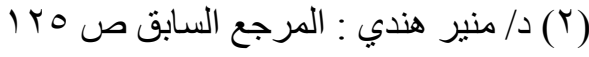


تتميز به من السرعة في التنفيذ دون الانتظار وبمقتضى أمر السوق يطلب العميل من شركة السمسرة ان تتفذ له الصفقة على وجه السرعة دون إبطاء بأفضل سعر يمكن أن يجرى عليه التعامل . وغالباً ما يتم تتفيذه ذلك الأمر بسرعة وفى لحظات محدودة سواء كان بالبيع أو بالثراء لأنهلا يضمن سعراً معيناً (') . وخاصة في الأوراق المالية ذات السيولة العالية مثل أسهم المؤشر الثناثينى في البورصة المصرية . وتلتزم شركة السمسرة بالتعاقد بأحسن ما يكون حتى ولو لم ترد تلك العبارة في أمر العميل بل وردت بسعر السوق لأن ذلك مما يوجبه مبدأ حسن النية وواجب شركة السمسرة في تتفيذ الوكالة بما يجب عليها من عناية لازمة (؟) ـ فالمطلوب من شركة السمسرة ان تتفذ ذلك الأمر على خير ما يرام فتحصل على أقل سعر عند الشراء وأعلى سعر عند البيع لما في ذلك من تحقيق مصلحة العميل ،ومن عيوب ذللك النوع من الأوامر ان العميل مصدر الأمر لا يستطيع معرفة السعر الذى تم به تتفيذ الأمر إلا حينما تقوم شركة السمسرة بإخطاره ـ وعلى العميل أن يقبل السعر السائد في السوق دون مناقشة(־) . ثانياً : الأوامر المحدة

في هذا النوع من الأوامر يصدر العميل أمره الى شركة السمسرة وبطلب فيه من الثركة أن تتفذ له الصفقة المطلوبة بسعر معين يحدده العميل في الأمر وعلى هلى

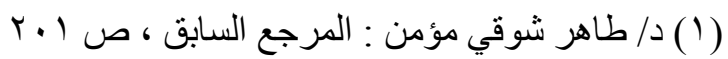

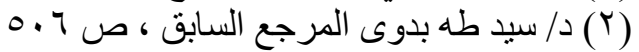

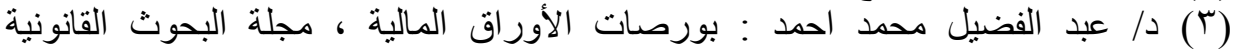

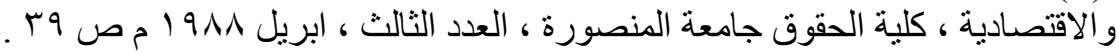

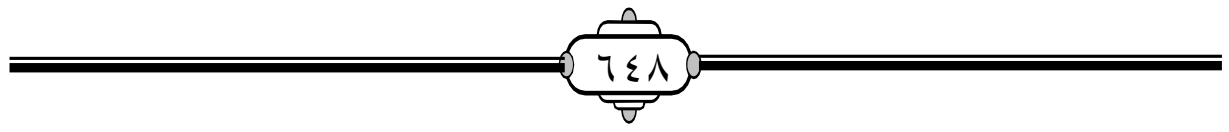


شركة السمرة أن تتفذ الأمر عندما يصل سعر الورقة المالية في السوق الى السعر المحدد ، وغالباً ما يكون مرتفعاً قليلاً عن سع السوق اللحظي في حالة البيع ومنخفضاً قليلاً عن سعر السوق اللحظي في حالة الثراء ـ

وقد تتفذ شركة السمسرة الأمر المحدد السعر بسعر أفضل مما ثم تحديده وعندئذٍ يقال أن السمسار على أحسن مما حدده العميل ، وشركة السمسرة لا تتنظر حتى يصل سعر الورقة المالية الى السعر المحدد في أمر العميل ، وإنما تقوم بتسجيل الأمر على شاشة التداول في البورصة وتدخله إما في العروض أن كان بعاً أو ضمن الطلبات إن كان أمر شراء ـ وينفذ الأمر حينما يصل سعر الورقة المالية إلى السعر المحدد الم

وهذا النوع من الأوامر لله مزية معرفة العميل مقدماً الحد الأقصى للقيمة التي سيدفعها إذا كان الأمر الصادر منه أمر شراء أو الحد الأدنى للقيمة اذا كان الأمر بيعاً ومما يعيب هذا النوع من الأوامر ان سعر السوق لا يصل الى السعر المحدد في الأمر ومن ثم لا تتفذ الصفقة حتى ولو كان الفرق بين السعرين ضئيلا ـ ومن هنا أجاز القانون للعميل أن يطلب تعديل الأمر المحدد السعر بأن ينزل العميل بالسعر قليلا في حالة البيع حتى يتمكن من تتفيذ الصفقات ('). أما إذا كان أمر العميل محدد السعر وكان سعر السوق مساوي السعر الأمر المحدد ولكن أمر العميل كان ترتيبه منأخراً عن غيره من الأوامر المحددة بنفس السعر ، فقد لا ينفذ هذا الأمر ولا مسؤولية على شركة السمسرة من جراء عدم التتفيذ ، لأن هناك قاعدة تقضى بأن الأوامر التي ثم فيها تحديد السعر وكان واحداً فيها حميعاً تنفذ أولا بأول وفق ترتيب لحظة ورودها. (1) د / سيد طه بدوى : المرجع السابق ، ص 9 ( 0 . 


\section{النوع الثاني: الأوامر المحدة لوقت التنفيذ}

هذا النوع من الأوامر هي التي يصدرها العميل الى شركة السمسرة ويطلب فيها أن تتفذ الأمر في وقت محدد ـ فالزمن في هذا النوع هو الفيصل في تتفيذ تلك الأوامر • وقد تكون هذه المدة يوماً أو اسبوعاً أو شهراً أو يكون الأمر مفتوحاً لا

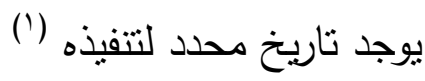 \\ أولاً: أوامر محددة بيوم}

يقصد بالأمر الصادر من العميل وكان محدداً بيوم أي يوم العمل الذى صدر فيه الأمر من العميل الى شركة السمسرة، من وقت صدوره الى نهاية جلسة العمل في البورصة في ذلك اليوم، وهذا النوع من الأوامر أكثرها شيوعاً وغالباً ما يكون مبنياً على توقعات مسبقة بأن ذلك اليوم هو أفضل يوم للتعامل في ورقة مالية

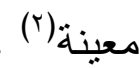

وكقاعدة عامة جرى العرف على اعتبار الأمر الغير محدد المدة أنه ليوم واحد ، وبالتالي يجب على شركة السمسرة أن تتفذه في أول جلسة وإلا اعتبر ملغياً، وأهم ما يميز هذا النوع من الأوامر أن ظروف السوق عرضة للتغير بين لحظة وأخرى فما يكون ملائماً لظروف العميل اليوم فقد لا يكون كذلك غداً .

\section{ثانياً : أوامر محددة بأسبوع}

يقصد بالأمر المحدد بأسبوع هو ذلك الأمر الذى يحدد فيه العميل أسبوع وقتاً 
والأسبوع هنا هو أسبوع العمل الذى صدر فيه الأمر من العميل ، وأسبوع العمل في البورصة المصرية يبدأ من الأحد الى الخميس فاذا أصدر العميل أمره محدداً بأسبوع كان أسبوع العمل الذى صدر فيه الأمر ، وينتهى بنهاية جلسة اخر يوم عمل في الأسبوع أياً كان وقت صدوره حتى ولو كان في اليوم الأخير

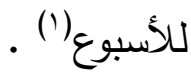

ثالثاً: أوامر محددة بشهر

ويقصد بذلك الأمر أن العميل يحدد فيه شهر مدة السريان لهذا الأمر ويقصد بالثهر هو شهر العمل الذى صدر فيه الأمر ، وهو الثهر الميلادي وينتهى هذا الأمر بانتهاء أخر يوم عمل في الثهر الذى طلب فيه العميل من الثركة أن نتفذ له فيه .

\section{رابعاً : الأمر المفتوح}

ويقصد به الأمر الذى يطلب فيه العميل أن يظل سأرى المفعول حتى ينفذ أو يقوم العميل بإلغائه ـ وفى البورصة المصرية لا يوجد منل هذا النوع من الأوامر لأن المشرع نص على أن الأوامر الغير محددة لوقت التتفيذ تتفذ في أول جلسة

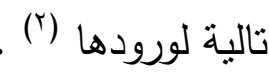

ويعطى هذا النوع من الأوامر للعميل حق إلغائه في أي وقت قبل أن تتفذ ، ولا يكون للسمسار حق المطالبة بالتعويض وذلك لأن طبيعة هذا الأمر قابلة للإلغاء في أي وقت . ويعاب على هذا النوع من الأوامر انه يرتبط بنوعين من المخاطر ، وهما مخاطر النسيان ومخاطر تغير المعلومات فالعميل قد ينسى أنه

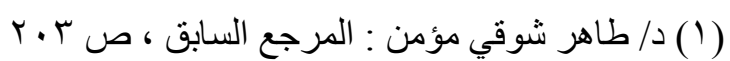

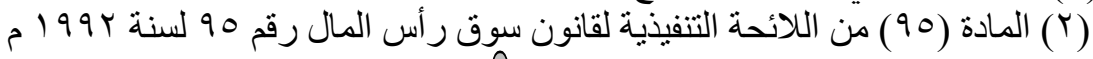


أصدر أمراً مفتوحاً نظر الطول الفترة التي انقضت من وقت إصدار الأمر ، ومخاطر تغير المعلومات ، فقد تحدث أي ظروف تغير من المركز المالي للشركة صاحبة الورقة المالية محل الأمر وتنكون تلاك التغيرات غير متوقعة بالنسبة للعميل مصدر الأمر فإن كان الأمر مفتوحاً وهو أمر شراء فقد تكون تلك الأخبار بالسلب على أمره الذى أصدره فإذا ما تم التتفيذ يصاب بخسارة كبيرة (') ـ لذلك يقع على شركة السمسرة ان تخطر العميل بالمعلومات المتغيرة التي تحدث . التوع الثالث : الأوامر التي تجمع بين سعر ووقت التنفيذ ويقصد بها تللك الأوامر التي تصدر من العملاء لشركة السمسرة وتكون محدداً بها سعر التنفيذ ووقته ولها صورنان من الأوامر كالآتي :

أولاً: الأمر المحدد للسعر خلال فترة معينة :

فهذا النوع من الأوامر يحقق مزايا الأوامر التي تحدد السعر ومزايا الأوامر

$$
\text { التي تحدد الزمن (r) }
$$

ثانياً : الأمر المفتوح في حدود سعر معين

هذا النوع من الأوامر يصدره العميل لشركة السمسرة ولا يحدد فيها وقتاً للتفيذ ولكنه يحدد السعر في هذا الأمر • وهنا يجب على شركة السمسرة ان ثتفذ الأمر حينما يصل سعر السوق للسعر المحدد في الأمر الصادر من العميل أو بسعر أفضل منه ـ أقل من السعر المحدد في أمر الشراء وأزيد من السعر المحدد في

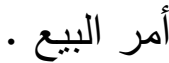

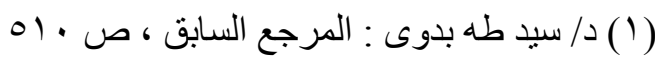

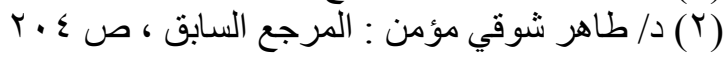




\section{النوع الرابع : الأوامر الخاصة}

توجد صور لبعض الأوامر الخاصة التي يصدرها العملاء لشركات السمسرة كى يقوموا بإبرام صفقات على أوراق مالية ، تعتمد تلك الأوامر على توقعات معينة يستخدم العميل في تلك التوقعات بعض البيانات الإحصائية عن الورقة المالية محل الأمر ويجرى عليها تحليلاً فنياً أو مالياً دقيقاً ، بمقارنة الأرباح أو الخسائر في الفترات الخالية وما يعادلها في السنوات الماضية ، ويستخدم العميل المضارب تلاك التوقعات في إصدار أوامره آملاً في تحقيق أرباح أو كي يقوم بحماية أرباح محققة فعلاً ، أو كي يتجنب خسارة قد تلحق به ، ومن أثنهر تللك الأوامر الخاصة

أوامر الإيقاف وأوامر الإيقاف المحدد وأمر التنفيذ حسب مقتضى الأحوال (') . 


\section{المطلب الثالث}

عمليات البورصة وأوامر العملاء في الفقه الإسلامي

تتم داخل بورصة الأوراق المالية عمليات بيع وشراء للأوراق المالية ـ من هذه العمليات ما هو حاضر عاجل ، ومنها ما هو آجل ، والبورصة المصرية يتم بداخلها النوع الأول من العمليات وهى العمليات الحاضرة دون الآجلة ولا بد من وجود أوامر للعملاء حتى يتسنى للسمسار أن يقوم بتتفيذ العمليات لصالحهم ، كل ذللك سوف أقوم ببحثه في هذا المطلب في الفقه الإسلامي كلّ في فرع مستقل على النحو التالي : n

الفرع الأول : العمليات الحاضرة في الفقه الإسلامي .

الفرع الثاني : العمليات الآجلة في الفقه الإسلامي .

الفرع الثالث : أوامر العملاء في الفقه الإسلامي • 


\section{الفرع الأول}

\section{العمليات الحاضرة في الفقه الإسلامي}

بداية العمليات الحاضرة "العاجلة " في سوق الأوراق المالية تطلق علي الصفقات التي يتم تتفيذها في قاعات التداول بالبورصة علي أصول مالية تمنل حقوقاً لأصحاب المشروع علي أصول مادية ، وتتحدد أسعارها من خلال آليات السوق وهما العرض والطلب عند أعلي سعر يعرضه المشترون وأدني سعر يقبله أو يطلبه البائعون، ويجري التقايض في هذه العمليات عند انتهاء العقد فوراً بتسليم

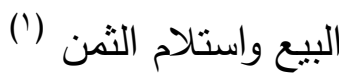

ومن ذلك لابد وأن نتعرف علي كيفية انعقاد هذا العقد في الفقه الإسلامي حتي يلبي لنا أن نخرج الحكم الثرعي لعمليات البيع الحاضرة في بورصة الأوراق المالية .بداية لا تتعقد العقود في الفقه الإسلامي إلا إذا وُجدت أركانها ، وأهم هذه الأركان "الصيغة" إذا هي التي تتشي العقود والصيغة هي الإيجاب والقول وبخلاف الصيغة فلابد من وجود عاقدين ومعقود علية ، وهذه هي أركان عقد البيع في الفقه الإسلامي عند جمهور الفقهاء من المالكية والثافعية والحنابلة (†) •

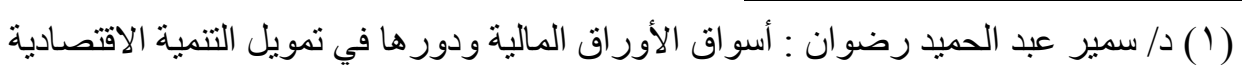

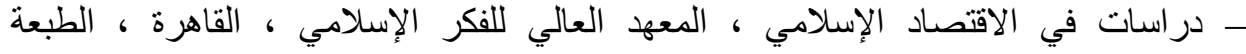

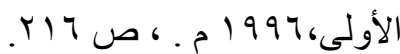

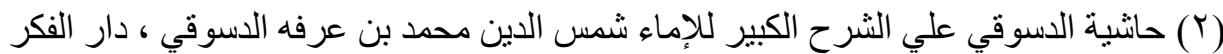

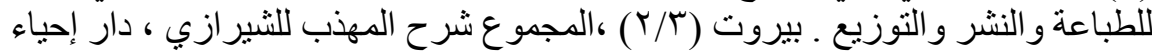

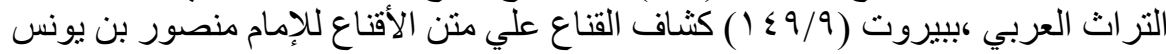

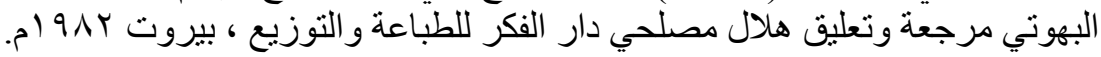

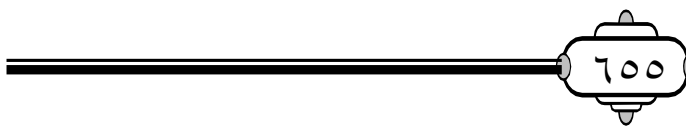

( ( $1 \leqslant 9 / \pi)$ 
ويري الأحناف أن ركن عقد البيع هو الصيغة (الإيجاب - والقبول ) وحدها

وغير ذلك يعتبرونه من الشروط (') .

وقد اختلف الفقهاء في تحديد الإيجاب والقبول ، فيرى الحنفية أن الإيجاب

هو ما صدر أولاً من أحد العاقدين ، والقبول : هو ما صدر من المتعاقد الثاني ،

لأنه يقع قبولا ورضاه لما أثبته الأول(r) .

وجمهور الفقهاء يرى الإيجاب: ما يصدر عن المملك ، وهو الثخص الذي

يكون منه التمليك كالبائع. والقبول: ما يصدر عن المتملك أب من يصير لله الملك

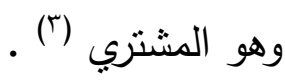

وفي مثل هذا النوع من المعاملات يبدى صاحب الأوراق المالية المبيعة

رغبته في بيعها ويبدي المشتري رغبته في شرائها، فيقوم سمسار كل منهما بأجراء

عملية البيع والثراء، وذلك بصفة أن سمسار كل واحد منهما وكيلا عنه، ويكون ذلك في مجلس العقد بين العاقدين حتي يتصل الايجاب بالقبول وفي العمليات الحاضرة "العاجلة " مجلس العقد هو الوقت الذي يصدر فيه القبول منالسمسار

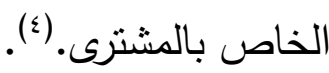

كذلك اختلف الفقهاء في المعقود عليه في عقد البيع هل هو المبيع والثمن أم أنه المبيع وحده دون الثمن

(1) بدائع الصنائع في ترتيب الثرائع ، الكاساني ، دار الكتب العلمية ،بيروت الطبعة الثانية

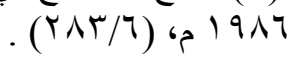

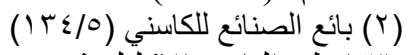
(r) (انظر التاج و الاكليل شرح منتصر خليل ،لمحمد بن يوسف البدري المواق ، طبعة دار (ع) د/ احمد محمد لطفي : المرجع السابق ص م/ آ وما بعدها 
كذلك اختلف الفقهاء في المعقود عليه في البيع هل هو المبيع والثمن أم أنه المبيع له حق الثنن ويري جمهور الفقهاء من المالكية والثافعية والحنابلة أن المعقود عليه في عقد البيع وهو المبع والثمن معاً وذلك لأن التعاقد لا يتم إلا بهما وكل منهما يوجد في مقابل الاخر (') .

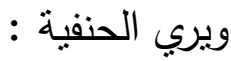

أن المعقود علية هو المبيع دون غيره وذلك لأن الثنن غير مقصود للمتعاقد بل هو وسيلة ألي المقصود وهو المبيع وذلك لأن الانتفاع يكون بالمبيع لا

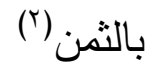

والراجع من الرأيين هو الأول والذي هو لجمهور الفقهاء من أن المعقود عليه هو المبيع والثمن معاً ، وذللك لأن المبيع إذا كان مقصوداً للمشتري فكذلك الثن مقصوداً للبائع ،وإذا كان الثمن وسيلة المشتري للحصول على المبيع ، فإن المبيع كذلك هو وسيلة البائع للحصول علي الثن -

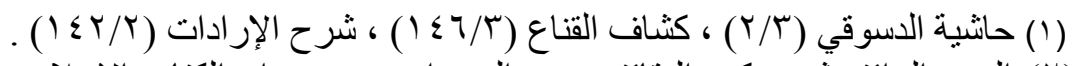

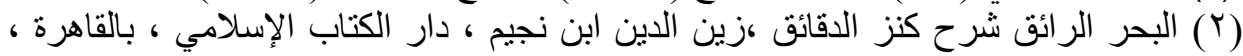

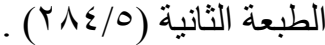

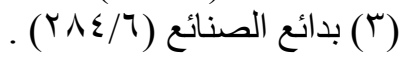

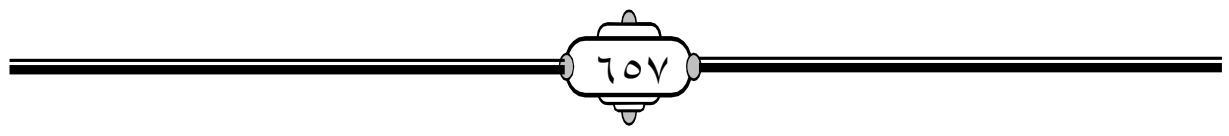




\section{شروط المبيع في الفقه الإسلامي :}

واشترط الفقهاء مجموعة من الثروط يجب نوافرها في المبيع حتي يكون محلاً

لعقد البيع منهم من يري أنها شروط للانعقاد والنفاذ والصحة للعقد وهم الحنفية (')، ومنهم من يري أنها شرط لصحة ونفاذ العقد وهم المالكية (؟)، ومنهم من يري أنها شرط الصحة فقط وهم الثافعية والحنابلة (r)

وأيا ما كان الامر فلابد من توافر شروط معينة في المبيع حتي يكون قابلاً للتعامل فيه حتي نستطيع الوقوف علي تحديد الحكم علي العمليات الحاضرة للبورصة ووجهة نظر الفقهاء في الثربعة الإسلامية وهذ الثروط هي : الثرط الأول : أن يكون المبيع موجوداً وقت التعاق

يثترط في المبيع الذي هو المعقود عليه في عقد البيع أن يكون موجودً وقت التعاقد فلا يعتمد العقد بدونه وهذا الراي للحنفية والثافعية والحنابلة في الأظهر (؛). وذلك في عقود المفاوضات فقط كالبيع أما في عقود التبرعات فيكتفون بإمكان

وحدوده في العقل ().

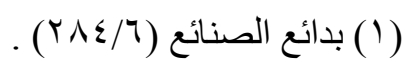

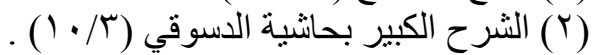

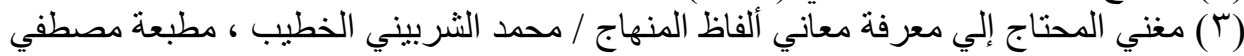

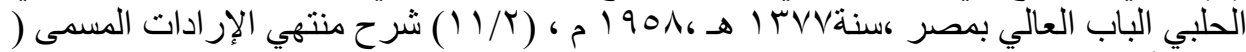

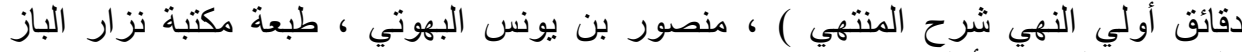

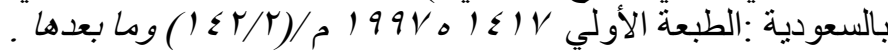

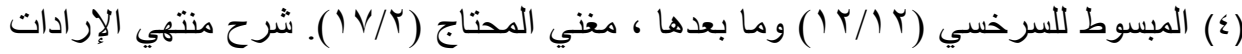
(0) الثرح الكبير بحاثية الدسوقي (T/ ع ( ) وما بعدها . 
بينما ذهب ابن تيمية وابن القيم إلي أنه لا يشترط في محل العقد أن يكون

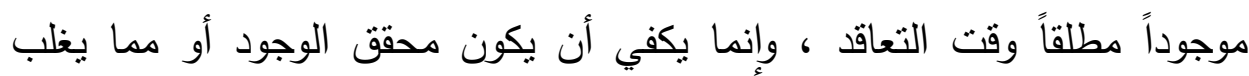
وجوده في العقل وذلك لان النهي عن بيع المعدوم ليس لذاته بل لما اثتتمل علية من الغرر المتمتل في عدم القدرة علي التسليم أو الجهالة المفضية إلي النزاع. فحيث لا يوجد غرر ولا جهالة فاحشة يكون العقد صحيحاً. وهذا هو الأقرب ألي روح الثريعة الإسلامية لما فيه من التيسير علي الناس فيمعاملاتهم ورفع

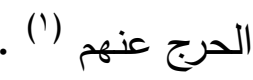

الثرط الثاني : أن يكون المبيع مقدوراً علي تسليمه : وذللك لان ما لا يُقدر علي تسليمه فهو شبيه بالمعدوم الذي لا يصح بيعه ،

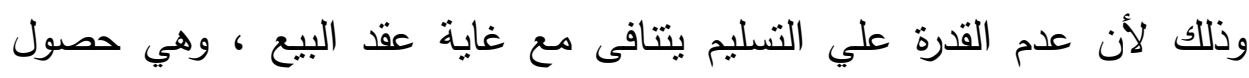

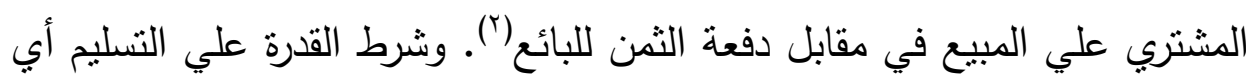

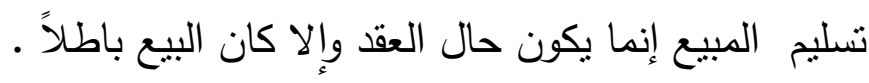
الثرط الثالث : أن يكون المبيع معيناً عن طريق العلم النافي للجهالة :

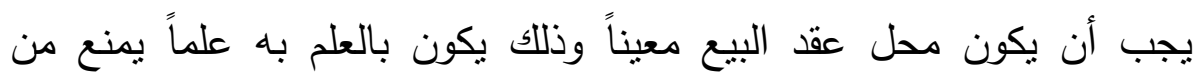
الجهالة الفاحشة التي تؤدي إلي المنازعة بين أطراف التعاقد ، ويكون المبيع معيناً

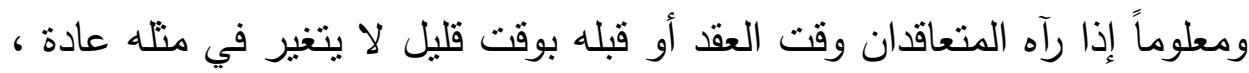

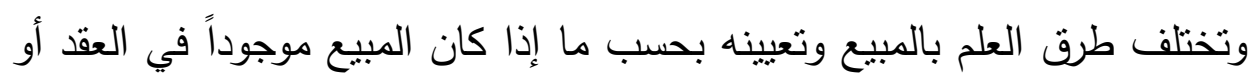

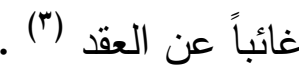

(1) د/ أنور دبور : الدذخل لدراسة الفقه الإسلامي (القسم الثاني ) أهم النظريات في الفقه

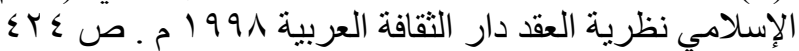

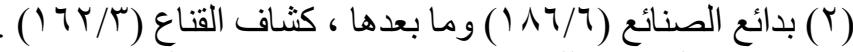

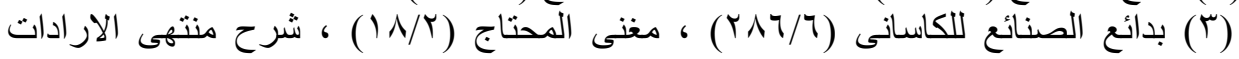

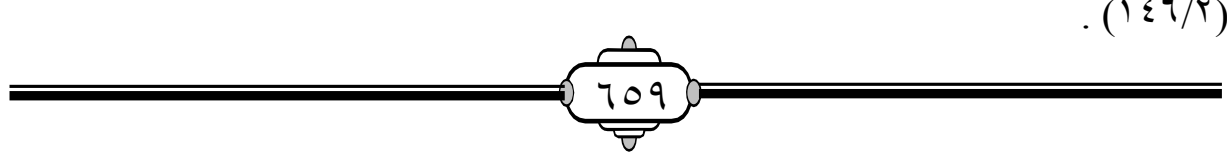




\section{الشرط الرابع : أن يكون المبيع مالاً متقوماً :}

وكذلك حتى يكون قابلاً للتعامل فيه وكذلك لا بد وأن يكون طاهراً ومنتفعاً به ،

كما يجب أن يكون المال مملوكاً لصاحبه خالياً من أي حق اله تعالى أو العباد ، فالذى ليس بمال لا يجوز التعامل فيه بالبيع بالاتفاق • وكذلك لا بد وأن يكون المال طاهراً منتفع به شرعاً ، فالنجس لا يعتبر مالاً ولا يصلح أن يكون محلاً لعقد البيع ، وكذلك لا بد وأن يكون المال متقومأ ويعتد به شرعاً ، فالخمر والخنزير لا يصلحان أن يكونا محلاً للبيع لأنها غير متقومه ، ولا بد أن يكون المال مملوكاً

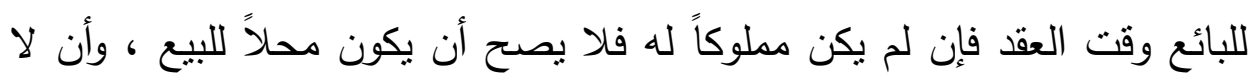
يكون به حق لله تعالى أو للعباد (') من كل ما سبق لا بد أن يتوافر في البيع أمور حتى يقع صحيحاً وهذه الأمور هي أن بنعقد بإيجاب وقبول صحيحين ، وأن يكون بين متعاقدين أو وكيليهما كما هو في حالة بيع الأوراق المالية ، فسمسار البائع وكيلاً عنه ، وسمسار المشترى وكيلاً عنه كذلك ، ويكون المعقد عليه موجوداً وقت العقد مقدوراً على تسليمه معيناً تعبيناً نافياً للجهالة وأن يكون كذلك مالاً متقوماً طاهراً منتفعاً به شرعاً مملوكاً

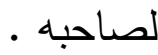

فإذا ما أردنا أن نطبق تلك الثروط التي اشترطها الفقهاء في المبيع وهو المحل في بيع الأوراق المالية ، وأيضاً الأركان التي نص عليها الفقهاء لعقد البيع دن وجود الصيغة والعاقدين على العمليات الحاضرة " العاجلة" التي يجرى بها العمل في البورصة نجد ما يلى :

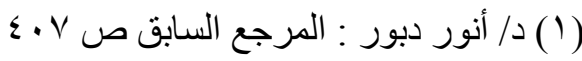

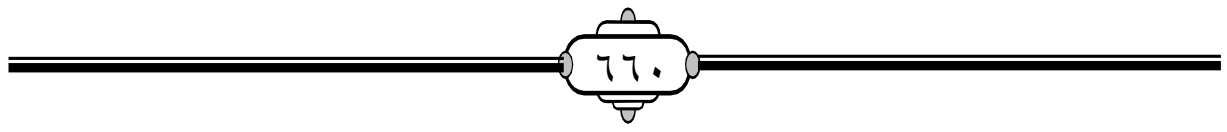




\section{أولاً : الإيجاب والقبول}

وهما اللذان يعبران عن إرادة العاقدين من إتمام العقد في العمليات الحاضرة ، ويشترط في الإيجاب والقبول أن يكونا واضحين من حيث دلالتهما على إرادة المتعاقدين ، والتي يعبر عنها كل من سمسار البائع وسمسار المشترى الوكيلين عنهما في إتمام عقد بيع الأوراق المالية ، وذلك بعرض المبيع من أوراق مالية على شاشة التداول في قوائم العرض ، وكذللك طلب المشترى من خلال سمساره الشراء بسعره المحدد للأوراق المالية المطلوب شرائها كذلك في قوائم الطلبات على شاشات التذاول في البورصة ، فذلك يدل صراحة على إرادة المتعاقدين ورضا

الطرفين في إتمام الصفقة وإمضاء عقد البيع (').

وقد توصل الققهاء المعاصرون في أبحاثهم الى جواز التعاقد بكل ما من شأنه أن يعبر عن إرادة المتعاقدين ، ومن ذلك آلات الاتصال الحديثة من التليفون والإنترنت والكمبيوتر والفاكس والتليكس والبريد الإلكتروني (؟) .

ثانياً : العاقدان

أي البائع والمشترى ، وفى العمليات الحاضرة للبورصة يوكل كل من البائع والمشترى سمساره الذى يقوم له بإتمام العملية حيث نص قانون سوق المال على ضرورة تدخل السمسار في عمليات بيع وشراء الأوراق المالية فيكون بذلك سمسار

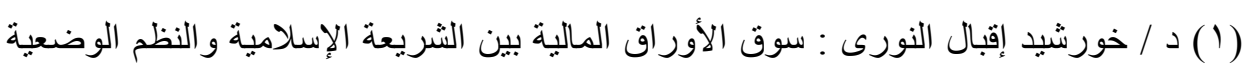

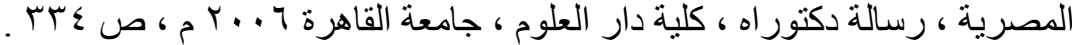

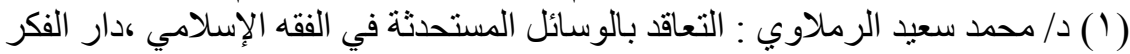

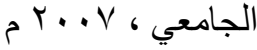


البائع وكيلاً عنه في إتمام العملية وكذلك سمسار المشترى ، وذلك جائز شرعاً في

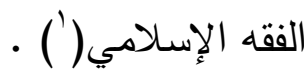

ثالثاً : المعقود عليه

وهو الأوراق المالية والثمن ، والمعقود عليه في العمليات الحاضرة يكون موجوداً عند إجراء العملية ، فعند إتمام العملية يتسلم سمسار المشترى الأوراق المالية المشتراة ، ويتسلم سمسار البائع الثثن المدفوع في شراء أوراق موكله التي باعها له وإن نراخى ذللك التسليم بعض الوقت لحين إجراء عملية المقاصة والتسوية بين

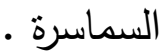

أما بالنسبة الى الثروط التي اشترطها الفقهاء في المبيع فهي منوافرة في العمليات(ץ) الحاضرة للأوراق المالية وذللك كثرط ملكية البائع للمبيع وملكية المشترى للثمن فيقوم سمسار البائع بالتأكد من ملكية البائع للأوراق المالية محل عقد البيع وكذلك سمسار المشترى يتأكد من ملكية موكله للثمن الذى سوف يشترى به ، وكذلك القدرة على التسليم فالأوراق المالية إما أن يتسلم صكوك ملكيتها السمسار من البائع وإما أن تكون مودعة في نظام الإيداع المركزي وهذا لتمام القدرة على التسليم ،وأما كون المبيع مالاً متقوماً فإن الأوراق المالية التي هي محل العمليات الحاضرة إنما تمثل حصة صاحبها بوصفه شربكاً في رأس مال الشركة التي أصدرتها فيأخذ عنها أرباحاً ويصوت في جمعياتها ويشارك أحياناً في إدارتها وذلك يمثل ملكية الثريك المشاعة في رأس مال الثركة ومقوماتها بقدر ما بملكه

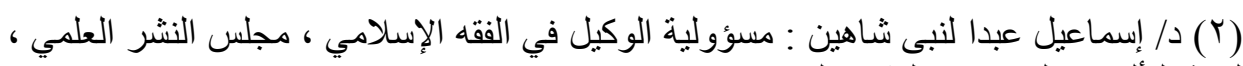

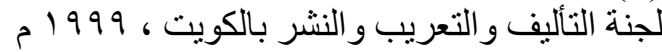

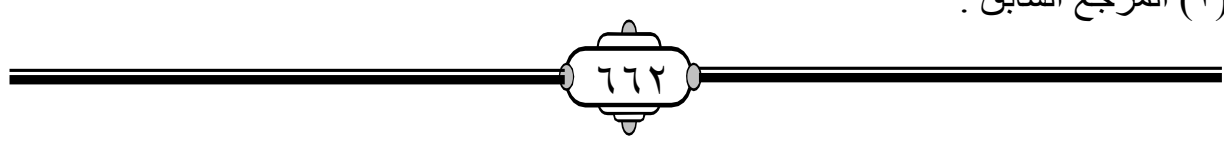




\section{عمليات البورصة وأوامر العملاء بين القانون التجاري والفقه الإسلامي}

من أسهم فيها ، ودائماً ما تقوم بيوت الخبرة والتثمين في تقويم تلك الأنصبة بحصر موجودات وممتلكات الثركة المصدرة للورقة المالية وقسمة ذلك الناتج على لكى لهيل عدد ما أصدرته من أوراق مالية فينتج عن ذلك استخراج القيمة العادلة للورقة

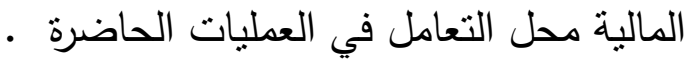

من كل ذللك نخلص إلى الحكم الثرعي على العمليات الحاضرة في البورصة

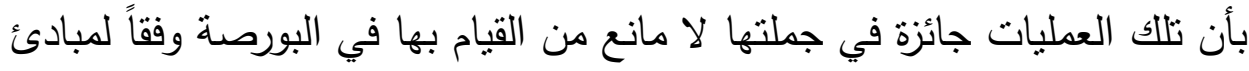
الثريعة الإسلامية الغراء وذلك لأن العمليات الحاضرة نتوافر بها شروط وضوابط البيع والثراء التي أقرها فقهاء الثريعة الإسلامية فلا شبهة في التحريم طالما لهال

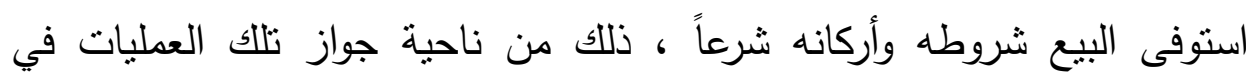

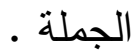

وهنالك تفصيل يرد على ذلك وهو بالنسبة للعمليات الحاضرة "العاجلة" التي يكون محلها أسهم شركات وكانت الثركات المصدرة لها تلتزم بالمعاملات الثرعية وكان نشاطها مشروعاً (') في الجملة كثركات القطاع الغذائي أو قطاع البناء

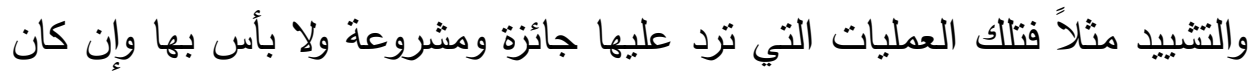
غير ذلك بأن كانت أسهم شركات تعمل في محرم كالربا الصريح أو تتجر في بـاني الخمر أو صالات القمار فذلك لا يجوز وهذه العمليات محرمة وغير جائزة

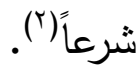

بالقامة لمزيد من التفصيل د/ محمد مصطفى : تقييم الثركات والأوراق المالية ، كليوباتر اللطباعة

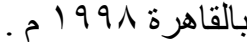

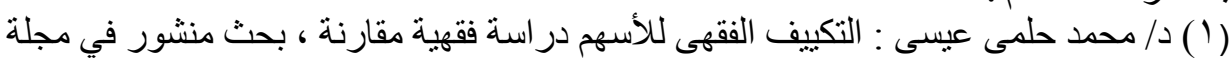

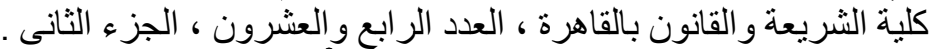


وكذلك بالنسبة للعمليات الحاضرة "العاجلة" التي يكون محلها سندات شركات وهى متعددة ،فأجمع الفقهاء المعاصرين على حرمة تلك العمليات لما في تلك السندات من عائد ثابت فيه رباً محقق ولهذا كانت العمليات الحاضرة في بيع وشراء السندات محرمة في جملتها (') .

وقد صدرت قرارات مجمع الفقه الإسـامي حول العمليات العاجلة في دورته من الأولى حتى الثامنة في مكة المكرمة والتي جاء فيها : إن العقود العاجلة على السلع الحاضرة الموجودة في ملك البائع التي يجرى فيها قبض فيما يشترط فيه القبض في مجلس العقد شرعاً هي عقود جائزة ، ما لم تكن عقود على محرم شرعاً ، إن العقود العاجلة على أسهم الثركات والمؤسسات حين تكون تلك الأسهم في ملك البائع جائزة شرعاً، ما لم تكن نلاك الشركات والمؤسسات موضوع تعاملها محرم شرعاً كثركات البنوك الربوية وشركات الخمور ، فحينئذٍ يحرم التعاقد في مي مهرد أسههها بيعاً وشراءًا ، إن العقود العاجلة والآجلة على سندات القروض بفائدة بمختلف أنواعها غير جائزة شرعاً ، لأنها معاملات تجرى بالربا المحرم (؟) . هذه هي قرارات مجلس المجمع الفقهي الإسلامي التي خلص إليها بشأن الحكم الثرعي 'آعمليات البورصة الحاضرة . وذللك مصداقاً لقوله تعالى : ( وأحل الله

(البيع ) ( البرعي ) (r)

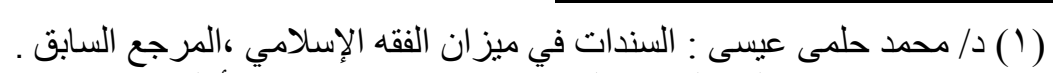

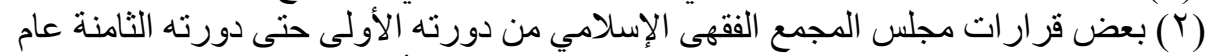

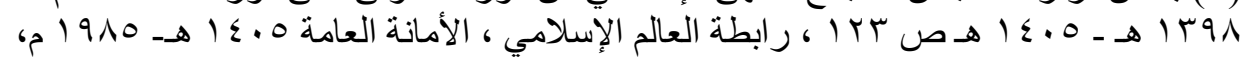

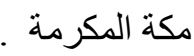

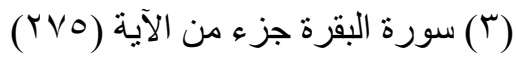


هذا من ناحية الحكم الثرعي للعمليات الحاضرة للبورصة ، وهذه العمليات لها صورتان لا بد وأن نستكثف الحكم الشرعي لهما وهما البيع على المكشوف والثراء بالهامش بصفتهما أهم صور العمليات الحاضرة في سوق الأوراق المالية .

\section{أولاً : الحكم الثرعي للبيع على المكثوف}

بداية يقصد بالبيع على المكثوف أن بييع الأوراق المالية التي لا بملكها على أمل أن ينخفض سعرها ثم يقوم بشرائها وإعادتها لمالكها إذا انخفض السعر وبستقيد بالفارق بين السعرين السعر المرتفع الذى باع به والسعر المنخفض الذى اشترى به عند التسليم ، أويقوم البائع باقتراض تللك الأوراق المالية من آخر في مقابل عمولة للمقرض ويسلمها للمشترى ثم يقوم بشراء تلك الأوراق المالية بعد ذلك من السوق للمقرض (') - (')

وهذا ما تم تعريفه وبيان صورته سابقاً والبيع على المكثوف عند الفقهاء أشبه

ما يكون ببيع الفضولي في الفقه الإسلامي وهو بيع الإنسان ما ليس عنده (؟) ، وصورته : أن يييع الرجل مال غيره بشرط إن رضى صاحب المال أمضى البيع ،

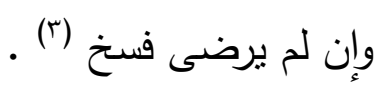

وللفقهاء المعاصرين في الحكم الثرعي للبيع على المكثوف في البورصة رأيان

$$
\text { في مدى الجواز لهذا النوع وعدم الجواز على النحو التالي : }
$$

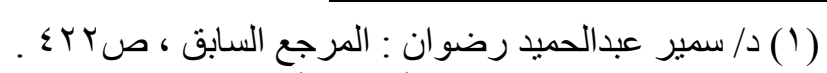

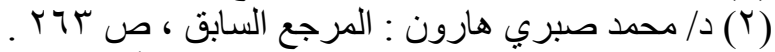

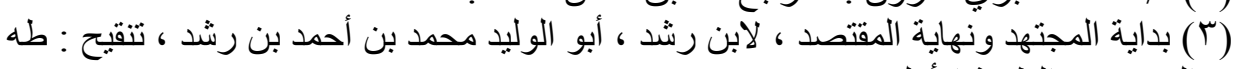

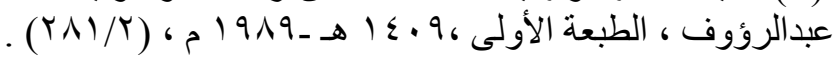




\section{الرأي الأول : عدم الجواز مطلقاً}

يرى أصحاب هذا الرأي من الفقهاء المعاصرين (') ،أن البيع على المكثوف بصورته الحالية الموجودة في البورصة غير جائز شرعاً ومنهى عنه ، واستخل أصحاب هذا الرأي من الكتاب والسنة والمعقول .

\section{أولاًا : من الكتاب}

استدلوا بقوله تعالى : ( يا أيها الذين أمنوا لا تأكلوا أموالكم بينكم بالباطل إلا أن تكون تجارة عن تراضٍ منكم ) (r) ـ فهذه الآية الكريمة نهت عن أكل أموال الناس بالباطل وهو كل طريق لم يكن مباحاً في الثريعة الإسلامية كالسرقة وما شابهها ويدخل ضمن ذلك بيع ملك الغير بدون إذنه ، فهو بيع بغير رضا المالك ، والإجازة اللاحقة لا تصحح عقدا باطلا .

\section{ثانياً : من السنة}

1 عليه وسلم فقلت : يأتني الرجل يسألني عن البيع ما ليس عندي ، أبتاع له من السوق ثم أبيعه ؟ثقال : "لا تبع ما ليس عندك " (r) . r - ما رواه عبدالهه بن عمر - رضى الله عنهما - قال :

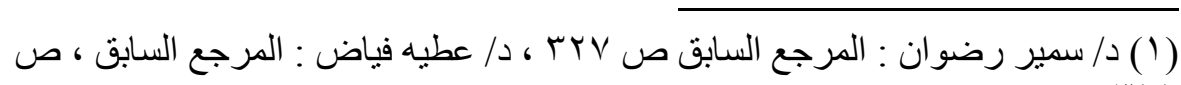

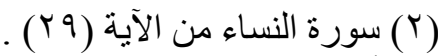

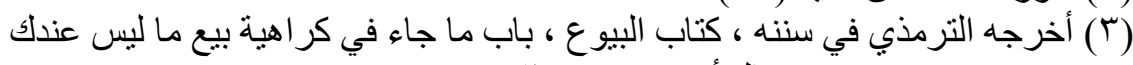

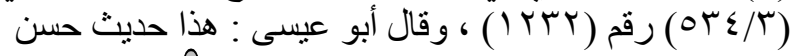


قال رسول الله صلى اله عليه وسلم : "لا يحل سلف وبيع ، ولا شرطان في

بيع ، ولا ربح ما لم يضمن ، ولا بيع ما لبس عندك " (') .

يدل الحديثان على النهى الصريح الصادر عن النبي يملك ، أي لا تبع ما لا تملك ومدار النهى أن البائع ليس أهلاً للبيع لأنه لا يمتلك المبيع وقت البيع ، وهذا فيه غرر فإذا باعه سلعة معينة ولكن لا يملكها ثم مضى بعد ذلك ليشتريها ويسلمها كان متردداً بين الحصول وعدمه فكان غرراً يشبه القمار المنهى عنه شرعاً ، من ذلك نجد أن البيع على المكثوف الذى يجرى العمل به في البورصة هو عين ما جاء في حديث حكيم بن حزام رضى اله عنه (r) . ا - أن البيع علي المكثوف قائم على الغرر والمقامرة ، حيث أن من يقوم به يتوقع انخفاض سعر الورقة المالية ، فلو خابت نوقعاته وارتفعت أسعار تللك الورقة المالية التي باعها فيمنى بخسارة فادحة . r - أن السمسار الذى يقرض ما لديه من أوراق مالية لعملائه الراغبين في البيع على المكثوف إنما يعينهم بذلك على القمار وهو محرم شرعاً وتصرف السمسار الذى يتصرف في مال غيره بدون إذنه فيه خيانة للأمانة وهى محرمة شرعاً ، وينطوي هذا البيع علي تضليل المشترى الذى اشترى أوراقاً مالية مقترضة وليست ملكاً لبائعها (r)

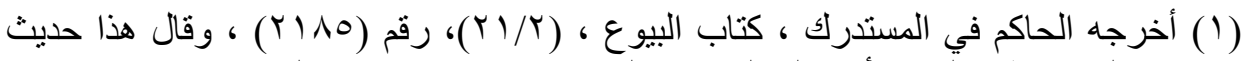

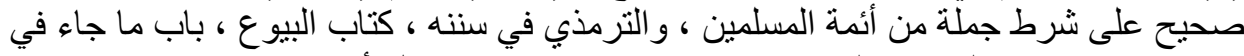

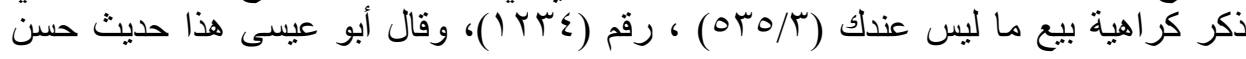

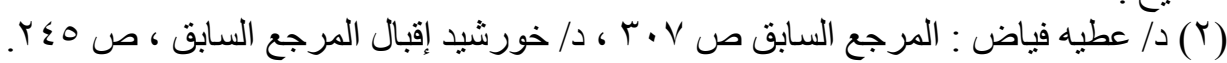
صحيح

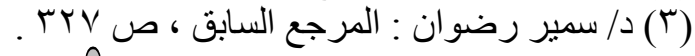




\section{الرأي الثاني : أنه يجوز شرعاً}

يرى أصحاب هذا الرأي من الفقهاء المعاصرين (') ـ أن البيع على المكثوف جائز شرعاً ولا مانع منه واستذلوا على ذلك بالآتي :

1 - أن بيع غير الموجود قد أصبح عرفاً يجرى عليه التعامل بين الناس في معاملاتهم العادية خارج البورصة، فإذا ما تم ذللك داخل البورصة وهى ذلك الكيان المنظم الذى له من القوانين ما يكفل تحقيق كل معاملاته دون إبطاء أو تأخير وعليه من الرقابة ما هو كفيل بأن يردع أي مخالف أو مقصر في عمله أو غير

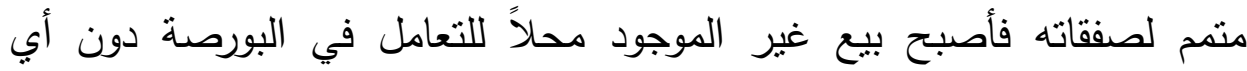

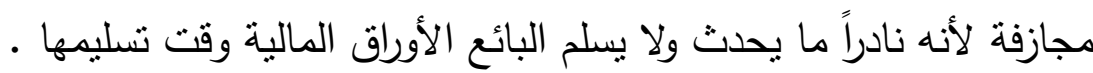
r - أن ما ورد في حديث حكيم بن حزام رضى اله عنه كان نهياً على سبيل النصح والإرشاد وليس على سبيل الإلزام ويذل على ذللك أن النهى ورد من النبي صلى الله عليه وسلم الى البائع وليس المشترى ، والبائع هو الحريص علي إتمام

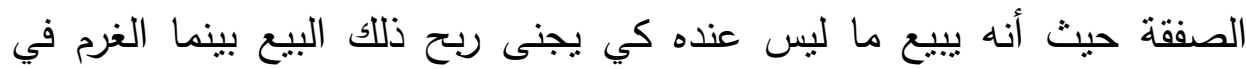

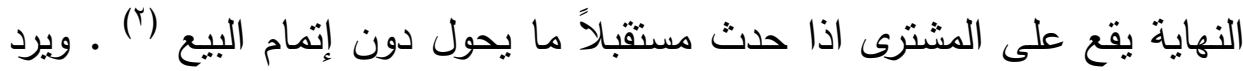

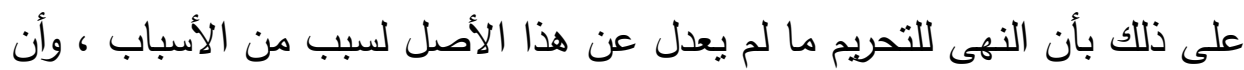
البيع على المكثوف هو عين ما جاء في حديث حكيم بن حزام عن بيع الإنسان

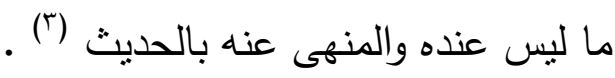

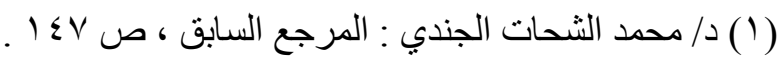

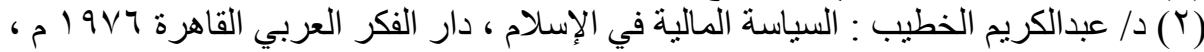
. IVV ص

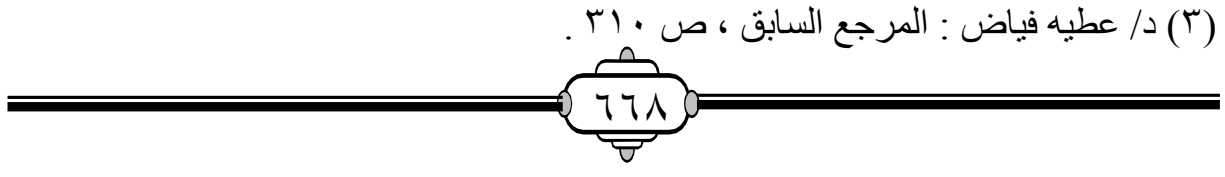


r-أن البيع على المكثوف يمكن تكييفه على أنه "بيع ما اشتراه قبل قبضه " وقد اختلف الفقهاء في ذلك والراجح عندهم أنه يعد أمرا جائزا لا غرر فيه وإنما هو من المعاملات الجائزة شرعاً (') . ويجاب على ذلك بأن الصورتين تختلفان فالبيع على المكشوف هو من باب بيع ما ليس عند الإنسان أصلاً بخلاف بيع المبيع قبل القبض فالمبيع موجود عنده في ذمته لكن لم يقبضه بعد (r) .

الرأي الراجح

بعد عرض أدلة من قال بعدم جواز البيع على المكثوف وأدلة من قال بجواز ذللك البيع من الفقهاء المعاصرين نرجح ما ذهب اليه الفريق الأول القائل بعدم جواز البيع على المكثوف وذللك لقوة أدلتهم ولأن ذلك لا يخلو من الغرر والمقامرة وأن النبي صلى الله عليه وسلم قد نهى عن بيع الإنسان ما ليس عنده ، وأن تصرف السمسار في الأوراق المالية المملوكة لأحد عملائه دون علمه ببيعها فيه خيانة للأمانة التي هي من أولى ما نصت عليه الثربعة الغراء بالرعاية والعناية ، من ذلك نرى أنه غير جائز شرعاً أن يبيع الإنسان ما لا يملك وهو البيع على هلى المكثوف في معاماتات البورصة .

\section{ثانياً الحكم الشرعي للشراء بالهامش :}

الشراء بالهامش هو أن يقوم العميل بسداد جزء من قيمة الصفقة التي بريد شرائها من الأوراق المالية يسمى هذا الجزء بالهامش المبدئي ، وتقوم شركة السمسرة بالثراء لله للصفقة كاملة بهذا الهامش المدفوع في مقابل فائدة تحصل عليها من العميل على الجزء المتبقي من ثمن الصفقة ، وتوضع الأوراق المالية

$$
\begin{aligned}
& \text { (Y) (1) دحمد الثحات الجندي : المرجع السبق ، ص هبا ا وما بعدها }
\end{aligned}
$$

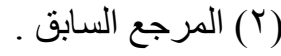


محل الصفقة كرهن لاى شركة السمسرة لضمان السداد ، وغالباً ما تقوم شركة السمسرة برهن هذه الأوراق محل الصفقة لدى البنوك لتحصل على قرض بضمانها بفائدة هي أقل من الفائدة التي تتقاضاها من العميل ، تمنل هذه الفائدة عقداً إضافياً لشركة السمسرة وتقوم أيضاً شركة السمسرة بإقراض هذه الأوراق محل هل هل هله الصفقة لمتعاملين آخرين يرغبون في إجراء بيع على المكثوف (') . وغالباً ما يلجأ العميل المضارب الى التعامل بالهامش اذا ما توقع ارتفاع أسعار الأوراق المالية مستقبلاً ، فإذا ما حدث ذلك استطاع أن يبيع ما اشتراه بالهامش ويسدد القرض وفوائده ويجنى أرباحاً إضافية من وراء ذلك ، فإذا ما حدث العكس وانخفضت الأسعار فقد حدثت الكارثة (؟) . والحكم الثرعي للشراء بالهامش اتفق الفقهاء المعاصرون على أن الثراء بالهامش بصورته السابقة محرم شرعاً واستدلوا على ذلك بالآتي : بلهي 1 - في الثراء بالهامش يوجد عقدان معا في صفقة واحدة لا يمكن فصلهما عن بعضهما ، وهما عقد شراء الأوراق المالية وعقد القرض أو اشتراط بيع وسلف معاً

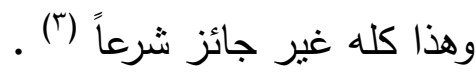
r - أن هذا النوع من البيوع حرام ، لأنه اجتمعت فيه عناصر ربا الديون الثلاثة وهى وجود دين مستقر في الذمة لطرف آخر ، والأجل ، وزيادة مشروطة مقابل

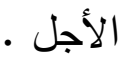

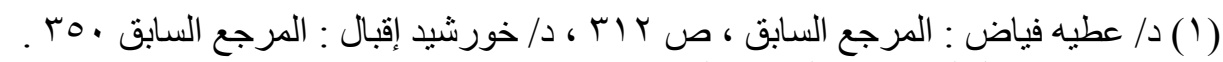

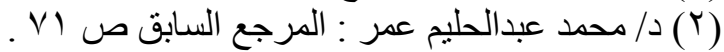

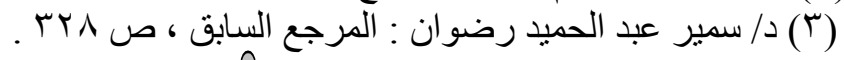




\section{عمليات البورصة وأوامر العملاء بين القانون التجاري والفقه الإسلامي}

r - أن هذا النوع من المعاملات يعتبر رباً واضحاً وصريحاً فالقرض الذى يقدمه السمسار للمشترى لمساعدته على شراء الأوراق المالية هو مقابل فائدة وهذا حرام • شرعاً

هذا وقد جاءت توصيات ندوة الأسواق المالية في البند السابع لها بما يلى : لا يجوز شراء السهم بقرض ربوي يقدمه السمسار للمشترى لقاء رهن السهم لما في ذلك من المراباة وتوثيقها بالرهن ، وهى من الأعمال المحرمة بالنص على لعن آكل الربا (') وموكله وكاتبه وشاهديه . لمربه من كل ما سبق نجد أن الحكم الثرعي للشراء بالهامش فيه اجماع على حرمته أبدا في ذللك النوع من التعامل من القرض الربوي الذى تصحبه فائدة ثابتة ومن هنا كان حراماً فلو أن شركة السمسرة قامت بإقراض العميل القرض المطلوب بدون فائدة تحصل عليها لأصبح هذا النوع جائزاً . 
الفرع الثانى

\section{العمليات الآجلة الباتة في الفقه الإسلامي}

بداية العمليات الآجلة في البورصة لا يقصد من ورائها سوى الانتفاع بفروق الأسعار فإذا تتبأ العميل المضارب بأن السوق يتجه نحو الارتفاع فيقوم بالثراء انتظاراً للارتفاع فيقوم ببيع تلك الأوراق التي اثتراها ويحقق أرباحاً عن طريق فروق الأسعار وهذا عميل مضارب على الصعود، وعلى العكس من ذلك عميلا يضارب على الهبوط ، وذلك إذا ما توقع انخفاض الأسعار مستقبلاً فيقوم ببيع أوراق مالية لا يملكها انتظارا لهجوط أسعارها مستقبلاً ثم يعاود شرائها عند الهبوط بسعر أقل مما باعها به مستقيداً من فروق الأسعار، فعند الشراء لا يدفع المضارب الثنن ولا يستلم الأوراق المالية المشتراة ، بل بؤجل ذلك ليوم التصفية ، وكذلك عند البيع فهو يبيع الأوراق التي لا يملكها وينتظر حتى يأتي موعد التصفية ليشتربها ثم يسلمها ويستلم الثن (') - (') ويجوز للمتعاقدين في العمليات الباتة تأجيل موعد التسوية النهائية حتى موعد تسويته لاحقاً ، ويؤدى تتفيذ البيع الآجل البات الى خسارة أحد الطرفين البائع والمشترى إلا في حالة ما إذا كان البيع يوم التصفية معادلاً لسعر البيع نفسه ، ويمكن أن يتضمن البيع الآجل البات ما يسمى" بشرط خيار التنازل عن الأجل " ويتمتع المشترى وحده بهذا لا الخيار ويلجأ إليه لإيقاف حركة الهبوط في السعر ويطلب من البائع تسليمه الأوراق المالية موضوع العملية قبل موعد التصفية كي

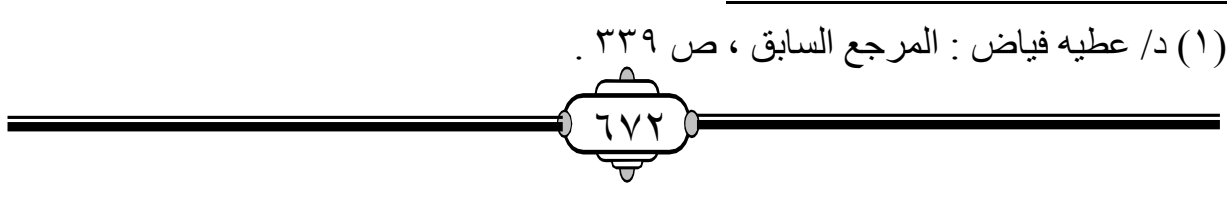


يقلل من خسارته ، فيقوم البائع بشراء تلك الأوراق من السوق فيرتفع سعرها مرة

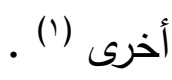

\section{الحكم الشرعي للعمليات الآجلة الباتة}

بعد معرفة مشروعية العمليات الآجلة الباتة التي تعقد في البورصة والتي سبق

بيانها ، مع الأخذ في الاعتبار أن البورصة المصرية حتى الآن لا تقوم بمباشرة تلك العمليات بداخلها ،نجد أن الفقهاء المعاصرين لهم في تلك العمليات رأيان هما:

\section{الرأي الأول : عدم الجواز مطلقاً}

وهذا الرأي قال به معظم الفقهاء المعاصرين (؟) . حيث يرون أن العمليات الآجلة الباتة غير جائزة واستدلوا على ذلك بالآتي :

ا - عدم انطباق أحكام عقد السلم على العمليات الآجلة الباتة وإن كان هناك نوع شبه وهو عدم ملك البائع للسلعة إلا أن ذلك لا يجعله جائزا ، لأن من شروط السلم قبض الثن في مجلس العقد، وإلا كان بيع دين بدين وهو منهى عنه بالإجماع ، والعمليات الآجلة الباتة قائمة على تأجيل الثمن والمثمن معاً فدخل ذلك تحت المنع المجمع عليه ، وأن المسلم فيه لا يجوز بيعه قبل قبضه إلا أن الواقع في العمليات الآجلة الباتة خلاف ذلك فيجوز للمشترى الأول أن بييع السلعة وهى في ذمة البائع

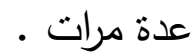

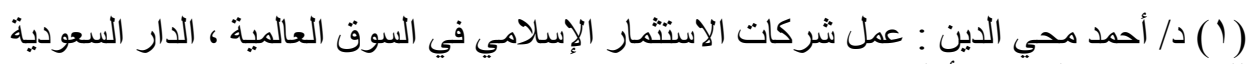

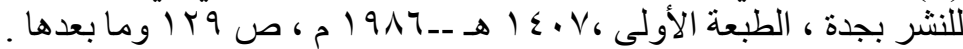

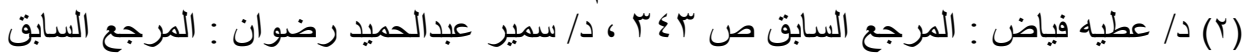

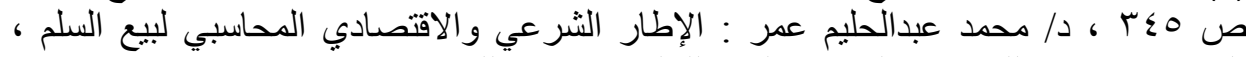

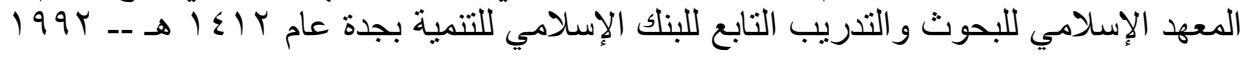

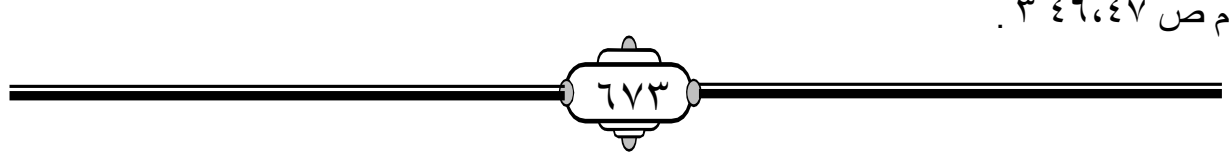


r - إن العمليات الآجلة الباتة مبنية على القمار والغرر، لأن غرض

المتعاملين من (') العملية لا يكون تشليم المبيع وقبض الثن في الموعد المحدد ، إنما يكون دفع فروق الأسعار مما يجعل تلك العمليات مبنية على المخاطرة والمقامرة حيث لا يربح أي طرف من المتعاقدين إلا وخسر الطرف الآخر ولذلك يتم تأجيل البدلين في العمليات الآجلة الباتة . r - إن العمليات الآجلة يتحقق فيها الربا ، وذلك في حالة دفع بدل التأجيل رباً ظاهر ، لأن هنالك بيع دين حال بثمن مؤجل مع الزيادة .... ع - التأجيل في العمليات الآجلة الباتة الى وقت مستقبلي ، يجعل تلك المدة مجهولة غير محددة ولا معلومة فتدخل فيها الجهالة من أوسع أبوابها والتي بها غرر منهى عنه شرعاً (r) .

الرأي الثاني : جواز العمليات الآجلة الباتة

يرى أصحاب هذا الرأي (َ). طالما أن الأوراق المالية محل نلك العمليات يجوز التعامل عليها ويملك المشترى المبيع ويملك البائع الثمن ويكون ملك المشترى للمبيع بمجرد عقد البيع الصحيح ولا يتوقف على التقابض ، وإن كان للتقابض أثره لكن عند الضمان ، ولا تقاس على عقد السلم ولا البيع إلى أجل ، ولكنها عقد بيع آجل في تسليم كلاً من البدلين .

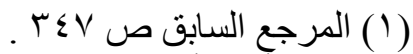

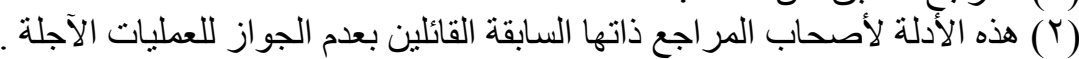

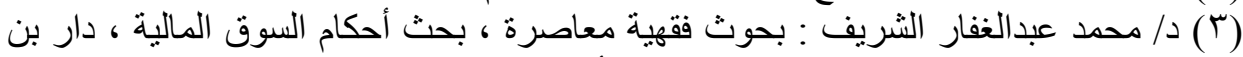

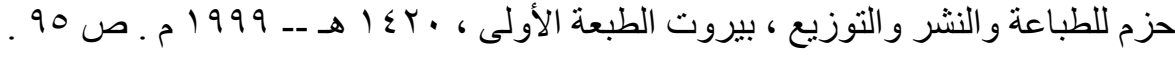


واستدل أصحاب هذا الرأي على ما ذهبوا إلبه من جواز العمليات الآجلة الباتة بالآتي : 1 - أن المالكية والحنابلة أجازوا اشتراط تأجيل الحق الى المدة التي يحددها

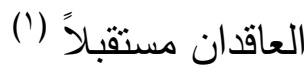

استتاداً الى حديث جابر رضى الله عنه أنه كان يسير على جمل قد أعياه

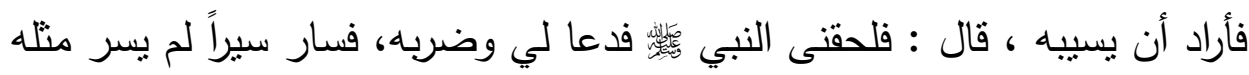
قال: (بعنيه (r) بوقية) قلت : لا ثم قال : ( بعنيه ) فبعته بوقية . واستثنيت حملانه إلى أهلي ، فلما بلغت أتيته بالجمل ، فنقدني ثمنه ثم رجعت فأرسل في إثري ، فقال : أتراني ما ماكسنك لآخذ جملك ؟ خذ جملك ودراهمك فهو للك (") . والدين لا خلاف في جواز تأجيله كذلك (๕) Y - واستدلوا كذلك بما جاء في الموسوعة الفقهية : أنه لا يمنع من انتقال الملك في المبيع أو الثمن كونها ديوناً ثابتة في الذمة ، إذا لم يكونا من الأعيان ، لأن الديون تملك الذمم ولو لم تتعين ، فإن التعيين أمر زائد عن أصل الملك ، فقد يحصل مقارناً له ، وقد يتأخر عنه الى أن يتم التسليم ل r - استدلوا كذللك من الفقهاء القدامى بما يأتي : أ - أن الثافعي يبيح كل بيع مؤجل أجلاً معلوماً أياً كان السعر قليلاً أم كثيراً لأنه بيع لملك الإنسان ولا يتضمن ضرراً وفيه المصلحة .

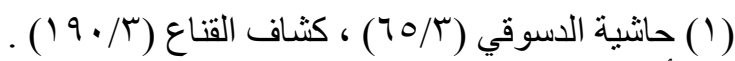

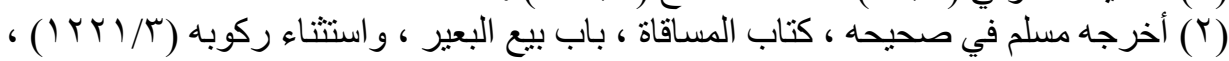
رقم (Y) (Y)

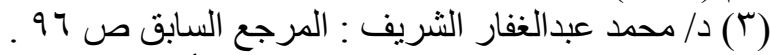

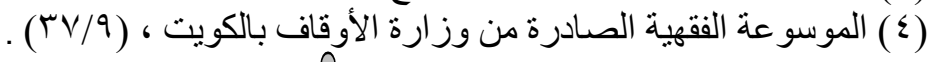


ب - أن الحنفية أجازوا البيع الآجل الذى تحدد أجله وكان الأجل فيه معلوماً، وفي غير الأصناف التي يجري فيها الربا .

ج - والمالكية قريبين من ذلك ، فالأجل المعلوم الخالي من الغرر ، والذى لا تكون المعاملة فيه بين الأموال الربوية ، يجوز البيع فيه .

د - والحنابلة لا يمنعون البيع الآجل لكنهم يحذرون شراء سلعة بثمن نقدى أقل

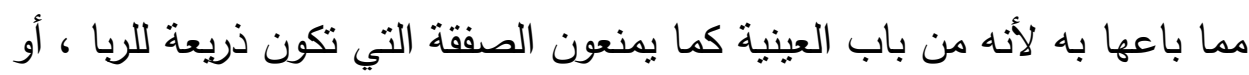
التي يكون الغرض من عقدها بين الطرفين الحصول(')على فروق السعرين سعر

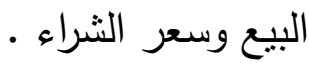

اعتمادا على عنصر الزمن وهو ما يكون في البيع نسيئة ، من كل ذلك ممكن القول بأنه لا مانع شرعاً من عقد العمليات الآجلة الباتة في البورصة وفقاً للشرائط الثرعية التي اشترطها الفقهاء ، من أن يكون الأجل معلوماً ، والمعاملات الآجلة في البورصة تتم في وقت معين ،هو وقت التصفية ، التي تجري مرتين كل

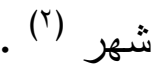
ع - أن المعقود عليه فلى العمليات الآجلة لا يكون ضمن الأصناف الربوية بل سلعة في مقابل شيء نقدى ، فثبهة الربا التي ينهى عنها الثارع منفية وغير موجودة .

فإن قيل أن عنصر الزمن هو المؤثر في الحصول على الفرق بين السعرين ، يجاب على ذلك بأن الزيادة قد لا تتحقق ، فيمكن أن ينخفض السعر ، والزيادة

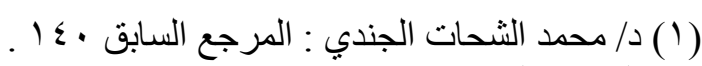

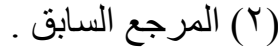

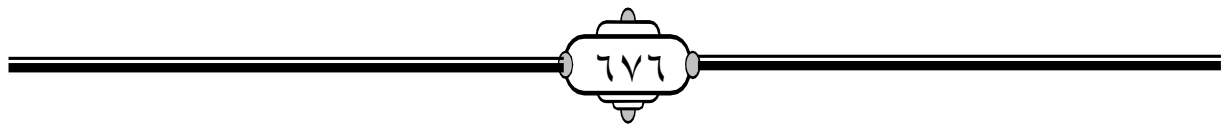


التي تحدث بسبب الأجل في البيع ليس من قبيل الربا المحرم الذى يقول فيه احد المتعاقدين للآخر عند حلول الأجل إما أن تقضى أو ترابي ، لأن الإبباء معناه أن يزيد الدين على المستحق في مقابلة إطالة الأجل ، بل تحدث الزيادة نتيجة ظروف العرض والطلب في البورصة وهو المعتبر الذى تتحدد على ضوئه الأسعار ارتفاعاً وانخفاضا ، والصفقات بين البائع والمشترى ثبرم بناءً على توقع السوق ، والتغير في العرض والطلب في فنرة التصفية المحدة وهذا لا بأس به في الشرع ، ومن ذلك فالعمليات الآجلة جائزة شرعاً (') 0 حلول أجلها ، فبناءً على ما قررته المذاهب الفقهية من حنفية ومالكية وشافعية وحنابلة ، هذا الشرط صحيح يلزم العمل به ، لأنهم جميعاً أجازوا شرط الخيار ، والعقد صحيح أيضاً ، ولا يتضمن غبناً .

ولا افتيات على حقوق أحد المتعاقدين ، ولا يعدو أن يكون اشتراطه للنظر والتروي لتلمس المصلحة في العقد واختيار ما يحقق النفع لمن شرط له ، 7 - بالنسبة لشرط دفع مبلغ على سبيل التعويض الذى يدفعه المضارب في العمليات الآجلة البسيطة في مقابل استخدامه لحق الإجازة أو الفسخ ، فهذا جائز عند غالبية الققهاء ، لأن هذا التعويض من قبيل الضمان الذى قال به الفقهاء وهنا مبلغ نقدى يدفعه المضارب ، وهو التزام مالي مشروع طالما نم برضا نفس وسماحه في البذل ، فالتراضي موجود فيه ، وتقرير هذا الضمان ناشئ عن إثبات (1) (1/ محمد الثحات الجندي : معاملات البورصة في الثريعة الإسلامية ، دار النهضة العربية،

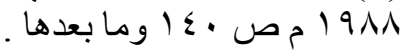

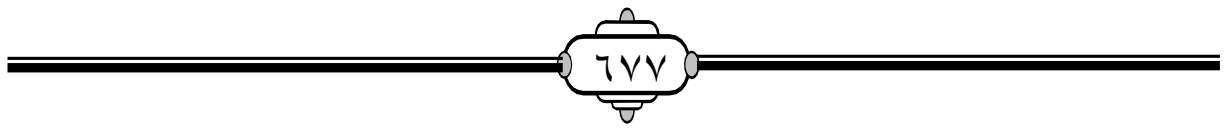


الحق للمضارب في تتفيذ العقد أو عدم تتفيذه ، نظراً لما يترتب على استخدام هذا الحق من تقويت منفعة على العاقد الآخر، أو جبر ضرر لحق به ، وهو من الثروط التي تلائم العقد، وهى عند الفقهاء مشروعة في الجملة ، فالعمليات الآجلة

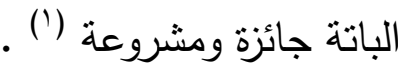

\section{الرأي الراجح : n}

بعد ثتاول آراء الفريقين من الفقهاء المعاصرين وأدلة كل فريق وما ذهب إليه، أميل الى ما ذهب إليه الفريق الثاني من الفقهاء من القول بجواز العمليات الآجلة الباتة وذلك لقوة أدلتهم وقوة ما استتدوا إلبه ، ولأن تلك العمليات صحيحة شرعاً ولا تقاس على عقد السلم ولا البيع (r) إلى أجل ولكنها عقد بيع آجل فيه تسليم كل من البدلين فكان جائزاً ومشروعاً.

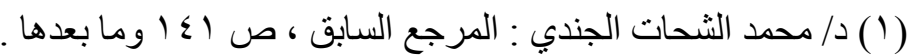

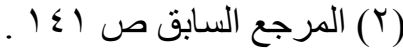




\section{الفرع الثالث}

\section{أوامر العملاء في الفقه الإسلامي}

تعتبر أوامر العملاء الصادرة منهم الى شركة السمسرة التي تقوم لهم بعملية بيع وشراء الأوراق المالية هي نقطة البداية لعمليات البورصة بأكملها، وأوامر العملاء هي بمثابة الإذن الذي يصدر من العميل الى شركة السمسرة بأن تقوم له بإجراء عملية معينة فإذا كان الأمر صادراً برغبة العميل في شراء أوراق مالية معينة كان أمر شراء، وإذا كان صادراً برغبته في بيع أوراق مالية معينة كان أمر بيع، وأمر البيع والثراء قد يكون محدداً بوقت معين كيوم أو أسبوع أو شهر • وقد يكون محدداً لسعر التنفيذ، وقد يجمع أمر العميل بين وقت التتفيذ وسعره. وقد يكون أمراً ضدن الأوامر الخاصة التي يصدرها العميل لثركة السمسرة، ويعتبر أمر العميل بمثابة إذن يصدر منه الى السمسار، وقد اثتنرط بعض الباحثين صدور هذا الإذن ضمن شروط عمل السمسار في الفقه الإسلامي، حتى يكون عمله صحيحاً، وذللك لأن العميل هو صاحب التصرف في ماله. وبالتالي فلا بد من اعتبار إذنه، ولأن السمسار وكيل ينوب عن العميل في عمل، والأصل أنه لا يجوز للوكيل البدا في العمل إلا بعد السماح له من الموكل بذللك، وأيضاً لأن إرادة العميل هي الأصل فيما يجريه السمسار من عمل له فذلك لا بد من اعتبارها، ويشترط في هذا الإذن أن يكون صريحاً واضحاً متضمناً لما يريده العميل من هن هـ هـ

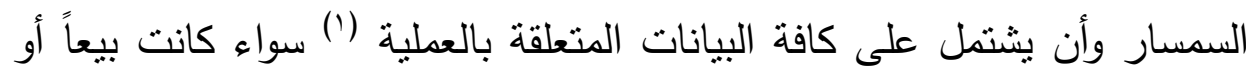

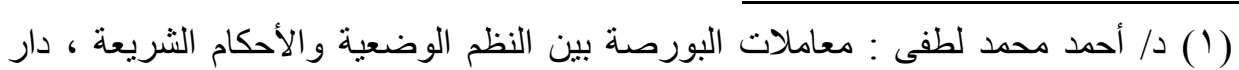

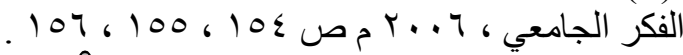




\section{الحكم الثرعي لأوامر البورصة}

أوامر البورصة لا شيء يثار حول ذلك التنظيم الإداري لها لأنها تهدف الى ضبط العمليات ضبطاً ناماً بعيداً عن التلاعب بالأسعار ، وإذا كان الأصل طبقاً الألئ للقواعد العامة أن كل مكلف رشيد يسنطيع أن يتعاقد بنفسه في كل ما هو مباح

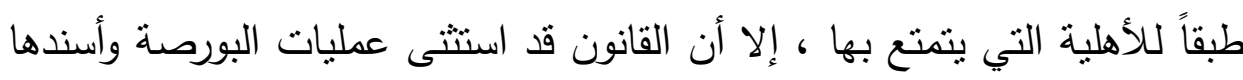

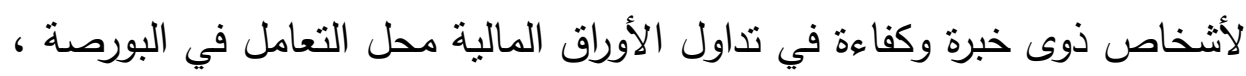
وهذا الاستثناء وإن كان يسلب عامة الأشخاص كاملي الأهلية من أن يتعاملوا

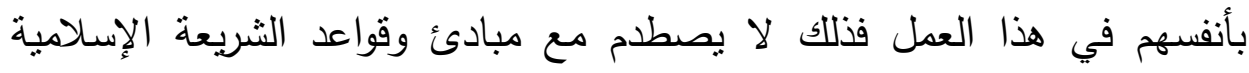

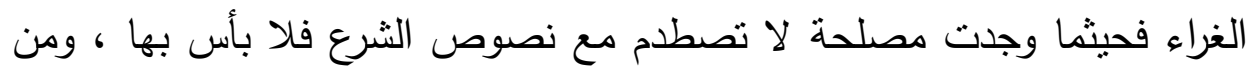
ذلك فإن نتظيم البورصة على هذا النحو لا مخالفة فيه للفقه الإسلامي، بل فيه

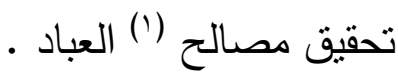

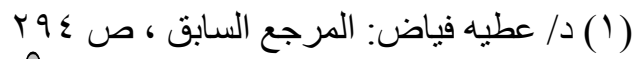




\section{الخاتمة}

بعد أن انتهيت بعون الله وتوفيقه من بحثى هذا تحت عنوان عمليات البورصة وأوامر العملاء بين القانون التجاري والفقه الإسلامي كان لزاماً على وضمن مسؤولياتي أن أسجل أهم النتائج التي توصلت إليها من خلال هذا البحث وكذلك التوصيات التي أوصى بها القائمين على سوق رأس المال، وكذللك الباحثين الذين يرغبون في كتابة أبحاث تخدم تللك العمليات ، وعلى الله

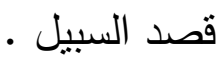

\section{أولاً التتائجج :}

1 - أن عمليات بورصة الأوراق المالية ليست نوعاً واحداً بل هي أنواع متعددة منها العمليات الحاضرة وهى التي يتم بمقتضاها تسليم الثمن الى البائع مقابل أن يقوم هو بتسليم الأوراق المالية المشتراة فور إتمام العمليات دون إبطاء أو تنأخير •

وبالنظر في قواعد ومقررات الثربعة الإسلامية الغراء وجدنا أن الحكم الثرعي لتلك العمليات الحاضرة في البورصة أنها جائزة في جملتها لا مانع من القيام بها وفقاً لمبادئ الثريعة الإسلامية.. وذللك لأن تلأك العمليات تتوافر بها شروط وضوابط البيع والثراء التي أقرها فقهاء الثربعة الإسلامية فلا شبهة في التحريم طالما استوفى البيع شروطه وأركانه شرعاً في الجملة. وتفصيل ذلك أنه بالنسبة للعمليات الحاضرة التي يكون محلها أسهم شركات وكانت الشركات المصدرة لها تلتزم بالمعاملات الثرعية وكان نشاطها مشروعاً في الجملة كشركات القطاع الغذائي أو قطاع النسيج مثنلً فتلاك العمليات التي تزد عليها جائزة ومشروعة ولا بأس بها وإن كان غير ذلك بأن كانت أسهم شركات تعمل في محرم 
كالربا الصريح أو تتاجر بالخمر وصالات القمار فذلك لا يجوز وهذه العمليات محرمة وعير جائزة شرعاً.

وكذلك العمليات الحاضرة التي يكون محلها سندات شركات وهي متعددة

فأجمع الفقهاء المعاصرين على حرمة تللك العمليات لما في تللك السندات من عائد ثابت فيه رباً محقق ولهذا كانت العمليات الحاضرة في بيع وشراء السندات محرمة في جملتها.

r - هناك نوع ثانٍ من العمليات تتم في البورصة وهى العمليات الآجلة إلا أن البورصة المصرية لا يتم بها تتفيذ منل تلك العمليات لكن نص عليها قانون التجارة المصري الجديد في إحدى مواده ـ والعمليات الآجلة منتوعة ومخلفة من بورصة الى أخرى ـ فإذا تبايع الطرفان على أن يتم تأجيل الثمن التسليم للأوراق المالية المبيعة وتأجيل دفع الثنن الى يوم معين يتققان عليه وهو يوم التصفية فهذا البيع يعد من العمليات الآجلة . ومن ناحية الثريعة الإسلامية الغراء وجدنا خلافاً فقهياً غنياً بالآراء والأدلة بين العلماء المجيزين لتلك العمليات والمانعين لها وخلصت إلى أن العمليات الآجلة الباتة القطعية جائزة شرعاً وذلك طالما أن الأوراق المالية محل ثلك العمليات يجوز التعامل عليها ويملك المشترى المبيع ويملك البائع الثمن ويكون ملك المشترى للمبيع بمجرد عقد البيع الصحيح ولا يتوقف على التقابض ـ وإن كان للتقابض أثنه لكن عند الضمان . ولا تقاس على عقد السلم ولا البيع إلى أجل ولكنها عقد بيع آجل فيه تسليم كل من البدلين.

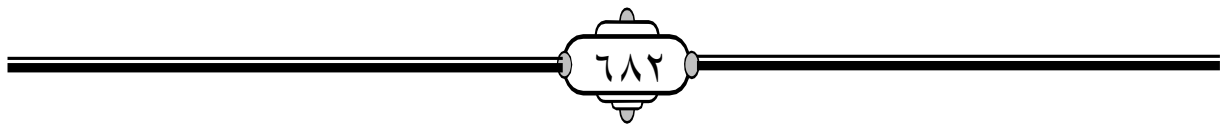




\section{عمليات البورصة واوامر العملاء بين القانون التجاري والفقه الإسلامي}

r - الثراء بالهامش وهو قيام العميل بسداد جزء من صفقاته نقداً والباقي

ينت بأموال مقترضة بفائدة ربوية ثابتة ، بشرط ضمان الأوراق المالية محل الصفقة.

وإذا نظرنا الى الثريعة الإسلامية وجدنا اتفاق بين العلماء المعاصرين على

أنه لا يجوز شرعاً لأنه يخالف أحكام المعاملات في الفقه الإسلامي في مختلف

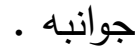

ع - البيع على المكثوف وهو أن يقوم العميل ببيع أوراق مالية غير مملوكة

له وقت صدور أمر البيع. على أن يقوم باقتراضها وتسليمها للمشترى ، وعندما نظرنا الى الحكم الثرعي في الفقه الإسلامي لتلك العمليات وجدنا أنها ممنوعة شرعاً وذلك لاحتوائها على العديد من المحظورات الثرعية .

ه - بالنسبة لأوامر العمليات وهى التعليمات الصادرة من العميل الى شركة

السمسرة بييع أو شراء الأوراق المالية وفقاً لثروط خاصة ، وفى الفقه الإسلامي بمثابة الإذن من العميل لوكيله بأن يبرم له عملاً ولا بأس بها شرعاً.

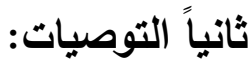

1 - ضرورة توجيه القائمين على دراسة وتدريس العلوم الثرعية ومنها ما

يخصنا وهو فقه المعاملات إلى دراسة الأصول القانونية والاقتصادية للمعاملات المعاصرة، حتى ينسنى لهم تكييف تلك المعاملات من الناحية الثرعية السليمة وإصدار الأحكام الثرعية لنلك المعاملات في ضوء مقررات وقواعد الثريعة

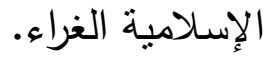

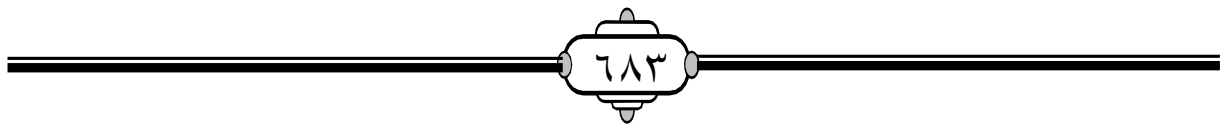


r - ضرورة تبصير وتوعية جمهور المتعاملين في البورصة بأحكام الثربعة الإسلامية لتلك العمليات التي يقومون بها ومعرفة ماهي الأوراق المالية التي يجوز لهم أن يتعاملوا بها وما هي تللك التي يحرم عليهم التعامل فيها . r - ضرورة قيام دراسات قانونية اقتصادية شرعية نتبثق من لجان متخصصة تعمل جاهدة على استحداث أدوات مالية إسلامية بديلة عن تلأك الأوراق المالية التي حكم الثرع الإسلامي بعدم جواز التعامل بها ـ وهذا ما قامت به فعلاً بعض الدول الإسلامية ، ومن تلأك الأوراق المالية الإسلامية سندات المقارضة الإسلامية وفقاً لقواعد الثربعة الإسلامية ووثائق الاستثمار الإسلامية . وأخيراً وليس آخراً إن شاء الله تعالى هذا هو جهدي البسيط المتواضع أسأل الله عز وجل أن يجعله منقبلاً وأن يكون خاصاً لوجهه الكريم ـ فإن كنت أخطأت فمن نفسي والثيطان وإن كنت قد أصبت فمن الله. ربنا لا تؤاخذنا إن نسينا أو أخطأنا وآخر دعوانا أن الحمد لله رب العالمين وصلى اللهم وبارك على سيدنا محمد وعلى آلة وصحبه وسلم • 


\section{فهرس المصادر والمراجع}

أولا : كتب التفسير

تفسير القرآن العظيم : للإمام ابن كثير ، الطبعة الأولى ^ •ـ ا هـ -- 199 1 م ، الناشر ، دار الحديث القاهرة . ثانياً: : كتب الحديث

1 - سنن الترمذي، محمد بن عيسى أبو عيسى الترمذي السلمى، دار إحياء

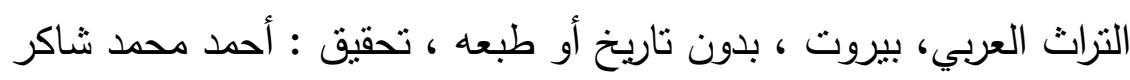
• وآخرون النرس

r - صحيح مسلم، مسلم بن الحجاج أبو الحسين القشيري النيسابوري ، دار إحياء التراث العربي ، بيروت ، بدون تاريخ ، تحقيق ، محمد فؤاد عبد الباقي •

بـالمستدرك على الصحيحين : محمد بن عبداله أبو عبداله الحاكم النيسابوري ، دار الكتب العلمية ، بيروت ، الطبعة الأولى ، 11 1 أهـ -- . 199 م ، تحقيق : مصطفى عبد القادر عطا .

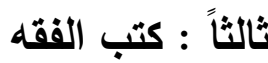
أ - الفقه الحنفي :

1 -- بدائع الصنائع في ترتيب الثرائع ، لعلاء الدين أبى بكر بن مسعود

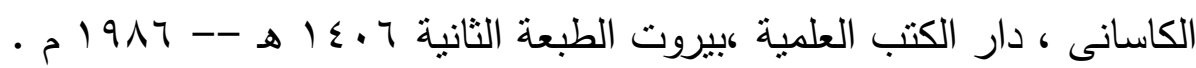
r -- البحر الرائق شرح كنز الدقائق ،زين الدين بن نجيم ، دار الكتاب الإسلامي ، بالقاهرة ، الطبعة الثانية . r -- المبسوط : لشمس الدين السرخسي ، طبعة دار المعرفة ، بيروت .

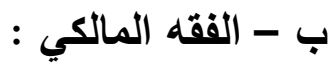


1 - بداية المجتهد ونهاية المقتصد ، لأبى الوليد محمد بن رشد القرطبي ، (الحفيد) ، دار الفكر ، بيروت ، 10 ، 10 هـ -- 1990 م • r -- - حاثية الدسوقي علي الثرح الكبير للإماء شمس الدين محمد بن عرفه الاسوقي ، دار الفكر للطباعة والنشر والتوزيع • بيروت .

r - - التاج والإكليل شرح مختصر خليل ،لمحمد بن يوسف البدوي ، المواق طبعة دار الكتب العلمية ، بيروت بدون تاريخ • ؟ -- الثرح الكبير على مختصر خليل ، لأحمد بن محمد بن أحمد الثهير بالدردير ، مطبوع مع حاثية الدسوقي ، دار الفكر بيروت .

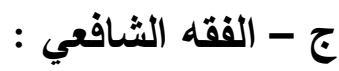
1 - المجموع شرح المهذب: ليحيى بن شرف النووي : دار إحياء التراث العربي بيروت .

r - مغني المحتاج إلي معرفة معاني ألفاظ المنهاج: للشيخ الشربيني الخطيب على منن منهاج النووي، طبعة ، مصطفى الحلبى بمصر •

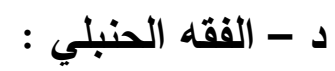

1-- كثناف القناع علي منن الإفناع للإمام منصور بن يونس بن إدريس البهوتى

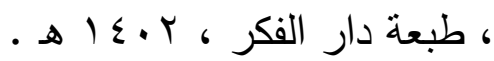

r -- شرح منتهي الإرادات المسمى ( دقائق أولي النهي شرح المنتهي ) ) لمنصور بن يونس البهوتي ، طبعة عالم الكتب ، بيروت ، بدون ناريخ • رابعاً : الكتب الشرعية الحديث 1-- د/ أنور محمود دبور : المدخل لدراسة الفقه الإسلامي (القسم الثاني ) أهم النظريات في الفقه الإسلامي نظرية العقد دار التقافة العربية 1991 م ץ-- د/ محمد سعيد الرملاوي : التعاقد بالوسائل المستحدثة في الفقه الإسلامي

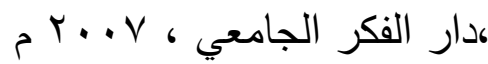


ب-- د/ إسماعيل عبد النبي شاهين : مسؤولية الوكيل في الفقه الإسلامي ،

مجلس النشر العلمي ، لجنة التأليف والتعريب والنشر بالكويت ، 1999 م ع -- د/ محمد صبري هارون : أحكام الأسواق المالية (الأسهم والسندات) ، دار

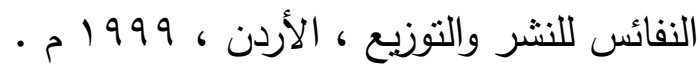
ه-- د/ عطيه فياض: سوق الأوراق المالية في ميزان الفقه الإسلامي ، الطبعة الأولى ، دار النشر للجامعات ، 991 19 م . צ-- د/ سمير رضوان : أسواق الأوراق المالية ودورها في تمويل التتمية الاقتصادية - دراسات في الاقتصاد الإسلامي ، المعهد العالي للفكر الإسلامي ،

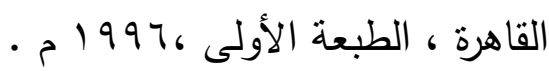
V- - د / محمد الثحات الجندي : ضمان العقد أو المسؤولية العقدية في الثريعة الإسلامية ، دار النهضة العربية 911 ا م. 1-- د/ عبدالكريم الخطيب : السياسة المالية في الإسلام ، دار الفكر العربي

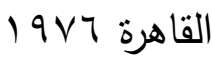
9-- د/ أحمد محي الاين : عمل شركات الاستثمار الإسلامي في السوق العالمية

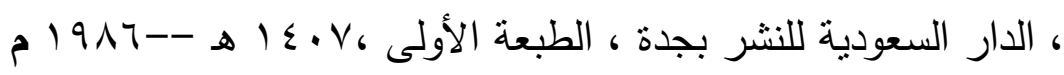
• - - د/ محمد عبدالحليم عمر : الإطار الشرعي والاقتصادي المحاسبي لبيع السلم ، المعهد الإسـامي للبحوث والتدريب التابع للبنك الإسلامي للتتمية بجدة عام م 199r-- ه 1 1 11-1/ محمد عبدالغفار الثريف : بحوث فقهية معاصرة ، بحث أحكام السوق المالية ، دار بن حزم للطباعة والنشر والتوزيع ، بيروت الطبعة الأولى ، ـ ـ ا هـ - $1999--$

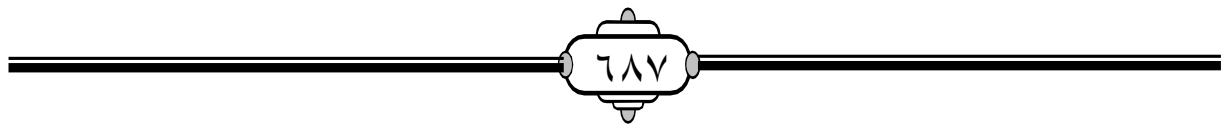


r ا -- د/ أحمد محمد لطقى : معاملات البورصة بين النظم الوضعية والأحكام

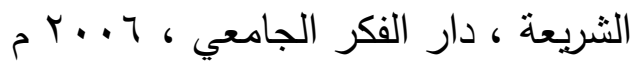

با -- د/ محمد الثحات الجندي : معاملات البورصة في الثربعة الإسلامية ،

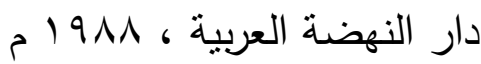

خامساً: الكتب القانونية الحديثة والمتخصصة 1 - - د/ عبد الفضيل محمد : بورصات الأوراق المالية ، مكتبة الجلاء الجديدة بالمنصورة.

r - د/ صالح راثثد الحمراني : دور شركات السمسرة في بورصة الأوراق المالية دار النهضة العربية ، الطبعة الأولى ، ؛ . . F م • ץ-- د/ منير إبراهيم هندي : الأوراق المالية وأسواق رأس المال ، منشأة المعارف . 19VV، الإسكندرية ،

ع -- د / محمد صالح بك : القانون التجاري ، الجزء الأول الطبعة الرابعة ، مطبعة فتح الله ألباس نوري وأولاده بممصر ، مبه ام. ه-- / محمد صالح : شرح القانون التجاري المصري ، مطبعة الاعتماد ، الطبعة

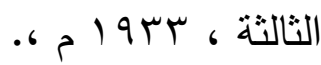
צ-- د// عبد الحكيم الرافعي : الاقتصاد السياسي ، الجزء الثاني ، مطبعة التأليف

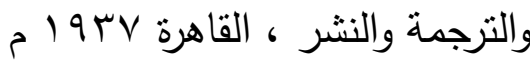
V- د- سمير عبد الحميد رضوان : أسواق الأوراق المالية ودورها في تمويل التتمية ، المعهد العالي للفكر الإسلامي ، دراسات في الاقتصاد الإسلامي ،

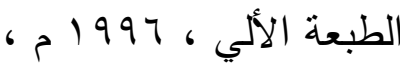
^-- د/ طاهر شوقي مؤمن : عقد بيع الأوراق المالية في البورصة ، دار

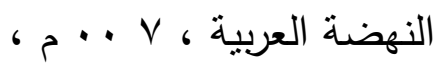

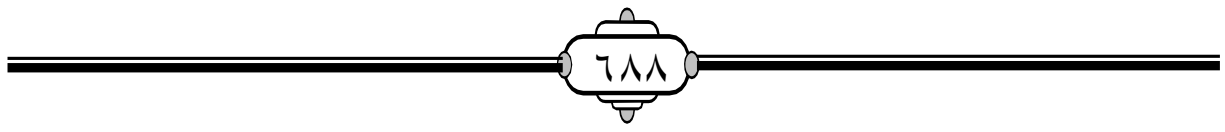


9-- د/ منير إبراهيم هندي : إدارة المنشأت المالية وأسواق المال ، منشأة

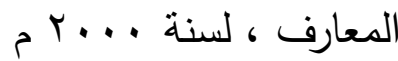

• والاقتصاد ، السنة الثامنة ، العدد الخامس ، مايو رب 19 م •

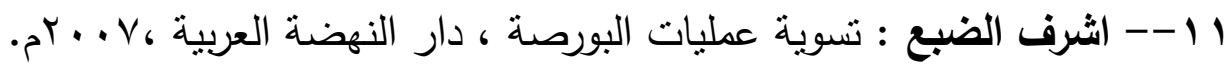
سادساً : الرسائل العلمية ا- د/ سيد طه بدوى : عمليات بورصة الأوراق المالية العاجلة والآجلة من

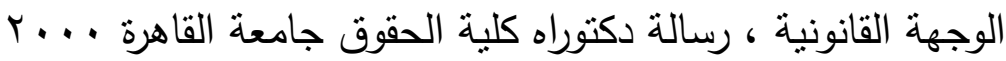
r -- د/ ماهر مصطفي إمام : النظام القانوني الخاص لثركات السمسرة في الأوراق المالية ، رسالة دكتوراه ، جامعة حلوان ، 1 ،. . ب م . بـأحمد سعيد الثهراني : عمليات الأوراق المالية العاجلة والآجلة ، رسالة

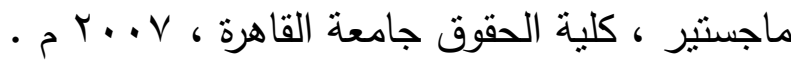
ع -- د/ خورشيد إقبال : سوق الأوراق المالية بين الثربعة والإسلامية والنظم

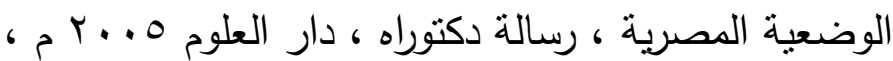
ه-- عبدالباسط وفا : بورصة الأوراق المالية ، ودرها في تحقيق أهداف تحول قطاع الأعمال العام الى الملكية الخاصة ، رسالة دكتوراه ، جامعة القاهرة . - 1997 سابعاً : البحوث والمقالات 1-- د/ عبد الفضيل محمد : بورصات الأوراق المالية ، مكتبة الجلاء الجديدة بالمنصورة. 
r - د / محمد عبدالحليم عمر : التفسير الإسلامي لأزمة البورصات ، بحث ضمن كتاب أزمات البورصات المالية ، الناشر مركز صالح كامل للاقتصاد الإسلامي $199 \mathrm{~V}$ r-- صادق حسنين باشا: بحوث في أعمال البورصات، مجلة القانون

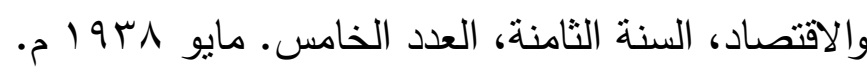
ع -- د/ منير إبراهيم هندي : بحث في أزمة البورصات العالمية ، مركز صالح مايو

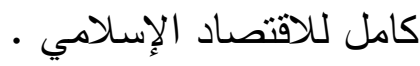

ه-- - د/ محمد حلمى عيسى : التكييف الفقهي للأسهم دراسة فقهية مقارنة ، بحث منشور في مجلة كلية الثريعة والقانون بالقاهرة ، العدد الرابع والعشرون ،

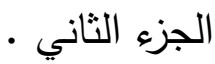
צ-- د/ محمد حلمى عيسى : السندات في ميزان الفقه الإسلامي ، بحث منشور في مجلة كلية الثربعة والقانون بالقاهرة ، العدد الرابع والعشرون ، الجزء الثاني. V-- ، د / محمد عبدالحليم عمر : الإطار الثرعي والاقتصادي المحاسبي لبيع السلم ، المعهد الإسلامي للبحوث والتدريب التابع للبنك الإسلامي للتتمية بجدة عام

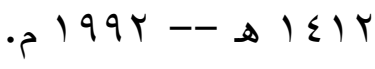

$$
\begin{aligned}
& \text { ثامناً : القوانين والقرارات }
\end{aligned}
$$

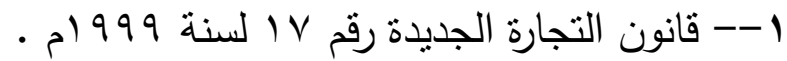
r-- قانون سوق رأس المال رقم 90 لسنة ب99 99 م . r -- قرارات مجلس المجمع الفقهي الإسلاهي من دورته الأولى حتى دورته

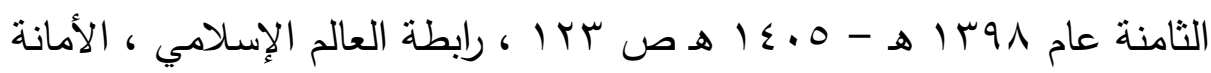
العامة 0. 1 ـ هـ 1910 م م ، مكة المكرمة ؟-- اللائحة التنفيذية رقم هب ا لسنة س99 1 بشأن نتظيم قانون سوق رأس المال رقم 90 لسنة ب99 199 م • 79. 